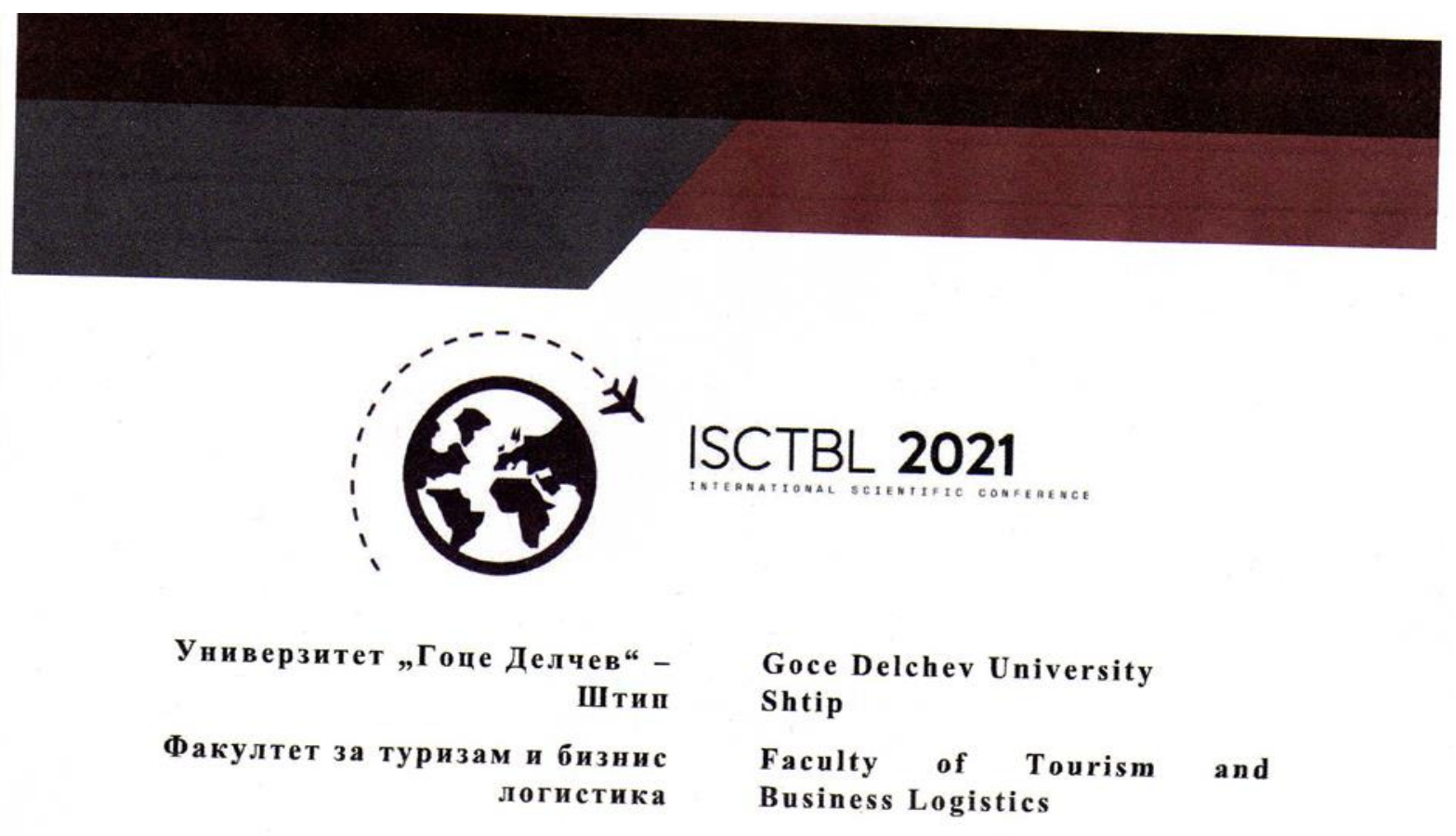

Четврта Меѓународна Научна Конференција

Fourth International Scientific Conference

$$
\begin{gathered}
\text { ПРЕДИЗВИЦИТЕ ВО ТУРИЗМОТ И БИЗНИС } \\
\text { ЛОГИСТИКАТА ВО } 21 \text { ВЕК } \\
\text { CHALLENGES OF TOURISM AND BUSINESS } \\
\text { LOGISTICS IN THE 21ST CENTURY }
\end{gathered}
$$

ЗБОРНИК НА ТРУДОВИ

CONFERENCE PROCEEDINGS 


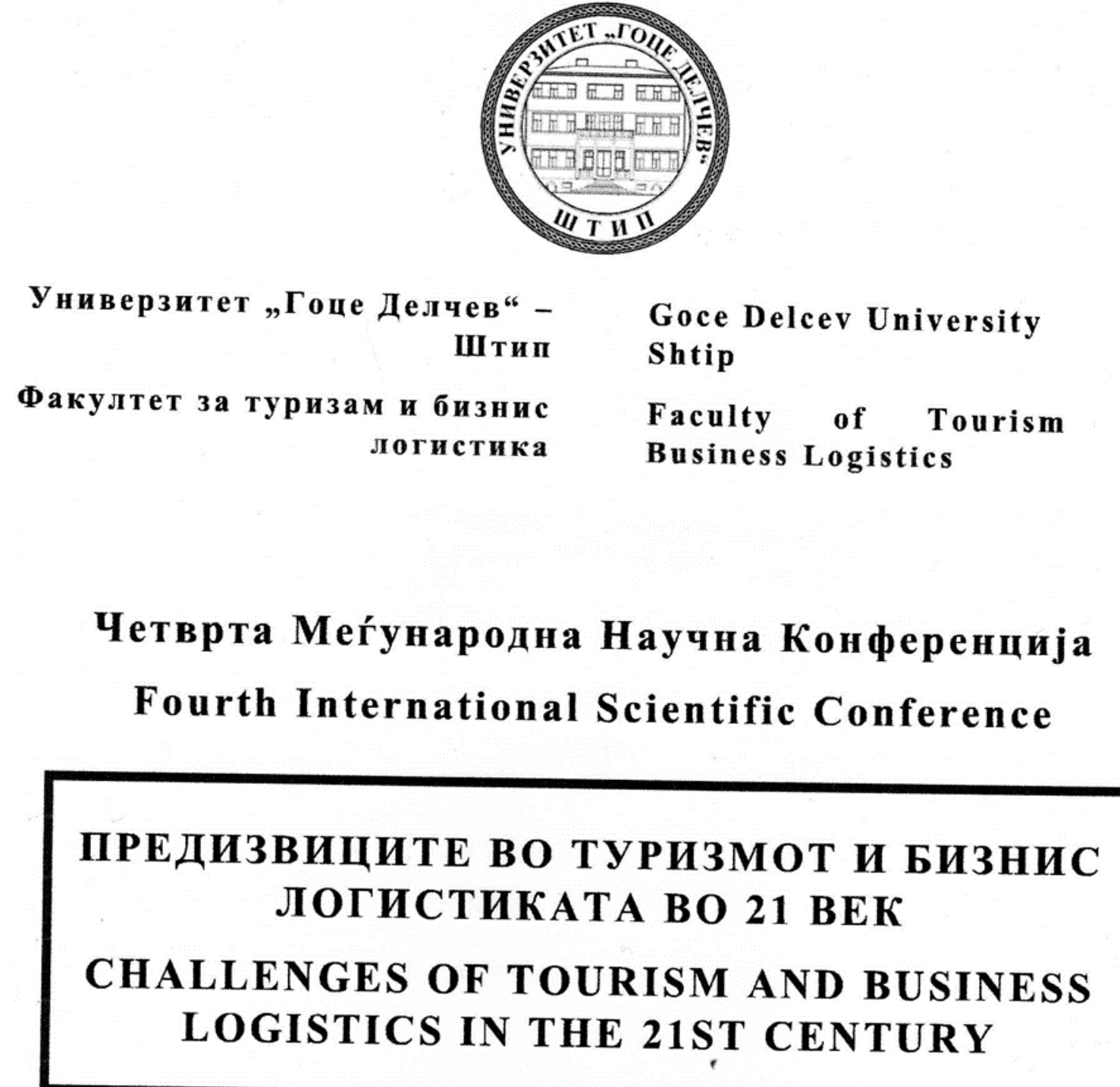

\section{ЗБОРНИК НА ТРУДОВИ CONFERENCE PROCEEDINGS}

19 ноември 2021 г. / November 19, 2021 


\section{Издавач:}

Факултет за туризам и бизнис логистика

Универзитет „Гоце Делчев“ - Штип

Крсте Мисирков, 10-А, 201, 2000, Штип, РС Македонија

Тел: +38932550 350

www.ftbl.ugd.edu.mk

www.ugd.edu.mk

DOI https://www.doi.org/10.46763/9786082448244

За издавачот:

д-р Татјана Бошков, декан

Организатор на конференцијата:

Факултет за туризам и бизнис логистика

Тираж: 146

\section{Publisher:}

Faculty of Tourism and Business Logistics

Goce Delchev University of Shtip

"Krste Misirkov" no.10-A P.O. Box 201 Shtip 2000, North Macedonia

Tel: +38932550350

www.ftbl.ugd.edu.mk

www.ugd.edu.mk

\section{DOI https://www.doi.org/10.46763/9786082448244}

For the Publisher:

Tatjana Boshkov, Ph.D. - Dean

Conference Organizator:

Faculty of Tourism and Business Logistics

Print circulation: 146

CIP - Каталогизација во публикација

Национална и универзитетска библиотека Св. „Климент Охридски“, Скопје

$338.48(062)$

658.6/.8:164(062)

МЕЃУНАРОДНА научна конференција (4 ; Штип ; 2021)

Предизвиците во туризмот и бизнис логистиката во 21 век : зборник на трудови / Четврта меѓународна научна конференција, 19 ноември 2021, Штип = Challenges of tourism and business logistics in the $21 \mathrm{st}$

century :

conference proceedings / Fourth international scientific conference, November 19, 2021, Shtip. - Штип :

Универзитет "Гоце Делчев", Факултет за туризам и бизнис логистика, 2021. - 390 стр. : илустр. ; $25 \mathrm{~cm}$

Трудови на мак. и англ. јазик. - Фусноти кон текстот. - Библиографија кон трудовите ISBN 978-608-244-824-4

1. Напор. ств. насл.

a) Туризам -- Собири б) Синџир на снабдување -- Логистички системи -- Собири 


\section{Организациски комитет:}

Проф. д-р. Татјана Бошков, Универзитет „Гоце Делчев“- Штип, Факултет за Туризам и Бизнис логистика, Штип, Република Северна Македонија

Доц. д-р. Наташа Митева, Универзитет „Гоце Делчев“ - Штип, Факултет за Туризам и Бизнис логистика, Штип, Република Северна Македонија

Доц. д-р Цветанка Ристова Магловска, Универзитет „Гоце Делчев“ - Штип, Факултет за Туризам и Бизнис логистика, Штип, Република Северна Македонија Доц. д-р. Душко Јошески, Универзитет „Гоце Делчев“ - Штип, Факултет за Туризам и Бизнис логистика, Штип, Република Северна Македонија

\section{Меѓународен програмски комитет:}

Проф. д-р. Татјана Бошков, Универзитет „Гоце Делчев“ - Штип, Факултет за Туризам и Бизнис логистика, Штип, Република Северна Македонија Доц. Д-р. Наташа Митева, Универзитет „Гоце Делчев“ - Штип, Факултет за Туризам и Бизнис логистика, Штип, Република Северна Македонија Доц. д-р. Цветанка Ристова Магловска, Универзитет „Гоце Делчев“ - Штип, Факултет за Туризам и Бизнис логистика, Штип, Република Северна Македонија Доц. Д-р. Душко Јошески, Универзитет „Гоце Делчев““- Штип, Факултет за Туризам и Бизнис логистика, Штип, Република Северна Македонија Проф. д-р. Мишко Џидров, Универзитет „Гоце Делчев“ - Штип, Машински факултет, Република Северна Македонија

Проф. д-р. Никола В. Димитров, Универзитет „Гоце Делчев“ - Штип, Факултет за Туризам и Бизнис логистика, Штип, Република Северна Македонија Проф. д-р. Цане Котески, Универзитет „Гоце Делчев“- Штип, Факултет за Туризам и Бизнис логистика, Штип, Република Северна Македонија Проф. д-р. Александра Жежова, Универзитет „Гоце Делчев“ - Штип, Факултет за Туризам и Бизнис логистика, Штип, Република Северна Македонија Доц. д-р. Оливер Филипоски, Универзитет „Гоце Делчев“- Штип, Факултет за Туризам и Бизнис логистика, Штип, Република Северна Македонија Проф. д-р. Зоран Темелков, Универзитет „Гоце Делчев“- Штип, Факултет за Туризам и Бизнис логистика, Штип, Република Северна Македонија Доц. Д-р. Душица Попова, Универзитет „Гоце Делчев“ - Штип, Факултет за Туризам и Бизнис логистика, Штип, Република Северна Македонија д-р Билјана Цоневска Гуњовска, Универзитет „Гоце Делчев“ - Штип, Факултет за Туризам и Бизнис логистика, Штип, Република Северна Македонија Проф. д-р. Тања Ангелкова Петкова, Универзитет „Гоце Делчев““- Штип, Факултет за Туризам и Бизнис логистика, Штип, Република Северна Македонија Доц. д-р. Васко Шутаров, МИТ Универзитет, Факултет за безбедност, Р. С. Македонија Проф. д-р. Глигор Бишев, Универзитет „Св. Климент Охридски“ - Битола, Економски факултет Прилеп, Република Северна Македонија Проф. д-р. Мадалина Теодора Андреи, Универзитет Хиперион, Факултет за општествени, хуманистички науки и природни науки, Оддел за географија, Романија Проф. д-р. Соња Квирога, Универзитет Алкала, Оддел за економија, Шпанија Проф. д-р. Алиса Флеишер, Хебрејскиот универзитет Јерусалим, Роберт Х. Смит, Факултет за земјоделие, Храна и Животна средина, Оддел за економија на животна средина и управување, Израел

Проф. д-р. Ноам Шовал, Хебрејски универзитет Ерусалим, Факултет за општествени науки, Оддел за географија, Израел

Проф. д-р. Нурија Елиса Морере Молинеро, Универзитет Реј Хуан, Шпанија 
Проф. д-р. Никола Хурвулиадес, Американ Колеџ Солун, Грција

Проф. д-р. Донила Пипа, Универзитет Марин Барлети, Економски факултет, Албанија Проф. д-р. Мохамед Фуад, Ариш Универзитет, Факултет за уметност, Египет

Проф. д-р. Френсис Вериза, Универзитет Толиара, Факултет за оппштествени науки, Мадагаскар

Проф. д-р. Октавиан Сербан, Букурешки Универзитет за Економија, Факултет за храна од земјоделие и економија на животната средина, Романија

Проф. д-р. Сабина Георгечи, Асоцијација за промоција на туризмот, Дробета ТурмуСеверин, Романија

Проф. д-р. Серафима Роскова, Молдовска академија за науки, Академија за економски науки на Молдавија, Република Молдавија

Проф. д-р. Стела Дерменџиева, Универзитет на Велико Трново Свети „Кирил и

Методиј“, Оддел за Географија, Бугарија

Проф. д-р. Марта Боровска Стефанска, Универзитет во Лоџ, Факултет за Географски

науки, Институт за градежна средина и Просторна, Полска

Проф. д-р. Јулиана Поп, Универзитет за економски студии, Факултет за бизнис и

туризам, Романиа

Проф. д-р. Елена Тома, Универзитет Хиперион, Факултет за општествени, хуманистички науки и природни науки, Оддел за географија, Романија

Проф. д-р. Ирина Лазар, Универзитет Хиперион, Факултет за општествени, хуманистички науки и природни науки, Оддел за географија, Романија

Проф. д-р. Озгур Јерли, Дужче Универзитет, Факултет за Шумарство, Оддел за пејсажи, Турција

Доц. д-р. Жарко Радјеновиќ, Универзитет во Ниш, Центар за иновации, Србија

Проф. д-р. Драго Цвијановиќ, Универзитет во Крагујевац, Факултет за Хотелски

менаџмент и Туризам Врњачка Бања, Србија

Проф. д-р. Дарко Димитровски, Универзитет во Крагујевац, Факултет за Хотелски

менаџмент и Туризам Врњачка Бања, Србија

Проф. д-р. Серџо Чипола, Универзитет во Палермо, Силиција, Италија

Доц. д-р. Марија Белиј, Универзитет во Белград, Факултет за географија, Србија

Доц. д-р. Андреј Мичовиќ, Универзитет во Крагујевац, Факултет за Хотелски менаџмент

и Туризам Врњачка Бања, Србија

Проф. д-р. Светлана Станкова, Универзитет во Шумен „Св. Константин Преславки“, Факултет за природни науки, Оддел за географија, регионален развој и туризмот, Шумен, Бугарија 


\section{Organizational committee:}

Prof. Tatjana Boshkov, Ph.D., Goce Delcev University of Stip, Faculty of Tourism and Business logistics, Stip, North Macedonia Assist. Prof. Natasa Miteva, Ph.D., Goce Delcev University of Stip, Faculty of Tourism and Business logistics, Stip, North Macedonia

Assist. Prof. Cvetanka Ristova Maglovska, Ph.D., Goce Delcev University of Stip, Faculty of Tourism and Business logistics, Stip, North Macedonia

Assist. Prof. Dusko Joseski, Ph.D., Goce Delcev University of Stip, Faculty of Tourism and Business logistics, Stip, North Macedonia International program committee:

Prof. Tatjana Boshkov, Ph.D., Goce Delcev University of Stip, Faculty of Tourism and Business logistics, Stip, North Macedonia Assist. Prof. Natasa Miteva, Ph.D., Goce Delcev University of Stip, Faculty of Tourism and Business logistics, Stip, North Macedonia Assist. Prof. Cvetanka Ristova Maglovska, Ph.D., Goce Delcev University of Stip, Faculty of Tourism and Business logistics, Stip, North Macedonia

Assist. Prof. Dusko Joseski, Ph.D., Goce Delcev University of Stip, Faculty of Tourism and Business logistics, Stip, North Macedonia

Prof. Misko Djidrov, Ph.D., Goce Delcev University of Stip, Faculty of Mechanical

Engineering, Stip, North Macedonia

Prof. Nikola V. Dimitrov, Ph.D., Goce Delcev University of Stip, Faculty of Tourism and Business logistics, Stip, North Macedonia

Prof. Cane Koteski, Ph.D., Goce Delcev University of Stip, Faculty of Tourism and Business logistics, Stip, North Macedonia

Prof. Aleksandra Zezova, Ph.D., Goce Delcev University of Stip, Faculty of Tourism and Business logistics, Stip, North Macedonia

Assist. Prof. Oliver Filiposki, Ph.D., Goce Delcev University of Stip, Faculty of Tourism and Business logistics, Stip, North Macedonia

Prof. Zoran Temelkov, Ph.D., Goce Delcev University of Stip, Faculty of Tourism and Business logistics, Stip, North Macedonia Assist. Prof. Dusica Popova, Ph.D., Dusica Popova, Ph.D., Goce Delcev University of Stip, Faculty of Tourism and Business logistics, Stip, North Macedonia Biljana Conevska Gunjovska, Ph.D., Goce Delcev University of Stip, Faculty of Tourism and Business logistics, Stip, North Macedonia

Prof. Tanja Angelkova Petkova, Ph.D., Goce Delcev University of Stip, Faculty of Tourism and Business logistics, Stip, North Macedonia Assist. Prof. Vasko Sutarov, Ph.D., MIT University, Faculty of Security Sciences, North Macedonia

Prof. Gligor Bishev, Ph.D., St. Clement of Ohrid University of Bitola, Faculty of Economics, Prilep, North Macedonia

Prof. Madalina Teodora Andrei, Ph.D., Hyperion University, Faculty of Social, Humanities and Natural Sciences, Department of Geography, Romania

Prof. Sonia Quiroga, Ph.D., University of Alcalá, Depatment of Economics, Spain

Prof. Aliza Fleischer, Ph.D., The Hebrew University of Jerusalem, The Robert H. Smith Faculty of Agriculture, Food and Environment, Department of Environmental Economics and Management, Israel 
Prof. Noam Shoval, Ph.D., The Hebrew University of Jerusalem, Faculty of Social Sciences, The Department of Geography, Israel

Prof. Nuria Elisa Morère Molinero, Ph.D., Universidad Rey Juan Carlos, Catedrática Historia Antigua, Spain

Prof. Nikolas Hourvouliades, Ph.D., American College of Thessaloniki, Greece

Prof. Donila Pipa, Ph.D., Marin Barleti University, Faculty of Economy, Albania

Prof. Mohamed Fouad, Ph.D., Arish University, Faculty of Arts, Egypt

Prof. Francis Veriza, Ph.D., University of Toliara, Faculty of Lettets and Human Sciences, Madagascar

Prof. Octavian Serban, Ph.D., Bucharest University of Economic Studies, Faculty of Agrifood and Environmental Economics, Romania

Prof. Sabina Gheorgheci, Ph.D., Mehedinţi Tourism Promotion Association, Drobeta TurnuSeverin, Romania

Prof. Serafima Roșcovan, Ph.D., Moldova Academy of Science, Academy of Economic Studies of Moldova, Republic of Moldova

Prof. Stella Dermendzhieva, Ph.D., University of Veliko Turnovo St Cyril and St. Methodius, Department of Geography, Bulgaria

Prof. Marta Borowska-Stefanska, Ph.D., University of Lodz Faculty of Geographical Sciences, Institute of the Built Environment and Spatial Policy, Poland

Prof. Iuliana Pop, Ph.D., University of Economic Studies, Faculty of Business and Tourism, Romania

Prof. Elena Toma, Ph.D., Hyperion University, Faculty of Social, Humanities and Natural Sciences, Department of Geography, Romania

Prof. Irina Lazăr, Ph.D., Hyperion University, Faculty of Social, Humanities and Natural Sciences, Department of Geography, Romania

Prof. Ozgur Yerli, Ph.D., Duzce University, Faculty of Forestry, Department of Landscape, Architecture, Turkey

Assist. Prof. Zarko Radjenovic, Ph.D., University of Nis, Innovation Center, Serbia

Prof. Drago Cvijanović, Ph.D., University of Kragujevac, Faculty of Hotel Management and

Tourism in Vrnjacka Banja, Serbia

Prof. Darko Dimitrovski, Ph.D., University of Kragujevac, Faculty of Hotel Management and

Tourism in Vrnjacka Banja, Serbia

Prof. Sergio Cipolla, Ph.D., University of Palermo, Italia

Assist. Prof. Marija Belij, Ph.D., University of Belgrade, Faculty of Geography, Serbia

Assist. Prof. Andrej Mićović, Ph.D., University of Kragujevac, Faculty of Hotel Management

and Tourism in Vrnjacka Banja, Serbia

Prof. Svetlana Stankova, University of Shumen "Konstantin Preslavski”, Faculty of natural science, Department of geography, regional development and tourism, Bulgaria 


\section{Содржина - Contents}

СЕСИЈА: БИЗНИС ЛОГИСТИКА И БИЗНИС АДМИНИСТРАЦИЈА ………………..... 15

SESSION: BUSINESS LOGISTICS \& BUSINESS ADMINISTRATION ………….......... 15

Tatjana Boshkov; Mishko Djidrov - CIRCURAL ECONOMY DEVELOPMENT

AND RESOURCE EFFICIENCY: EVIDENCE FOR MACEDONIA …............................... 17

Dushko Joseski; Tatjana Boshkov - MONETARY ECONOMICS: POST-KEYNESIAN

STOCK-FLOW CONSISTENT APPROACH (PK-SCF) VERSUS NEW-KEYNESIAN

DYNAMIC STOCHASTIC GENERAL EQUILIBRIUM (NK-DSGE)...............................25

Елизабета Митрева; Трајанка Стојменова; Златко Трајковски - ПРИМЕНА НА

МЕТОДОЛОГИЈАТА НА ДИГИТАЛНИ ЛОГИЧКИ СИСТЕМИ ВО ТРАНСПОРТОТ

ВО ТИМОКОМ ЛОГИЧКИ СИСТЕМ

Емануела Есмерова; Драшко Атанасоски - МОДЕЛИ НА РАЗВОЈ НА ЧОВЕЧКИТЕ РЕСУРСИ ВО ЕКОНОМИЈАТА НА ПРЕТПРИЈАТИЈА.................................................. 72

Марија Магдинчева-Шопова; Анета Стојановска-Стефанова - ПОЛИТИКИ И ПРАКТИКИ ЗА РАЗВОЈ НА СОЦИЈАЛНОТО ПРЕТПРИЕМНИШТВО 80

Анета Стојановска-Стефанова; Марија Магдинчева-Шопова; Христина Рунчева-Тасев - СОЦИО-ЕКОНОМСКОТО ВЛИЈАНИЕ НА КОВИД-19: МАКЕДОНСКИОТ СЛУЧАЈ СО РАЗВОЈ НА Е-ТРГОВИЈАТА 86

Žarko Rađenović - TRANSPORTATION MANAGEMENT SYSTEMS: LOGISTICS PERFORMANCE INDEX APPROACH.

Ивица Јосифовиќ; Игор Камбовски - ВИЗНАТА ПОЛИТИКА НА ЕВРОПСКАТА УНИЈА ВО ДОГОВОРОТ ОД ЛИСАБОН: ПРЕДИЗВИЦИ И ПЕРСПЕКТИВИ 109 Svetla Panayotova; Ventsislava Nikolova-Minkova - IMPORTANCE OF INTELLECTUAL PROPERTY FOR SMEs IN THE DIGITAL ECONOMY 120 Ventsislava Nikolova-Minkova - ECONOMIC PERSPECTIVES ON INTELLECTUAL PROPERTY MANAGEMENT. 128

Mimoza Serafimova; Bobana Stefanoska - SOCIO-ECONOMIC IMPACT OF COVID-19 CRISIS ON HUMAN RESOURCES AND COMPANIES 135 Александра Жежова - ОДНЕСУВАҢЕТО НА ЛИЧНОСТА И ПОЗИЦИЈАТА НА РАБОТНОТО МЕСТО 149

СЕСИЈА: ТУРИЗАМ, УГОСТИТЕЛСТВО И ГАСТРОНОМИЈА............................ 159 SESSION: TOURISM, HOSPITALITY \& GASTRONOMY........................................... 159 Dushica Popova; Natasha Miteva - SERVICE QUALITY MODELS IN HOSPITALITY INDUSTRY 160

Cvetanka Ristova Maglovska; Ivan Durgutov - REBUILDING TOURISM AND TRAVEL FOR THE FUTURE: POLICY RESPONSES TO THE CORONAVIRUS (COVID-19)..... 167 
Љупчо Јаневски; Климент Наумов - ЕКОТУРИЗМОТ КАКО СПЕЦИФИЧНА

ТУРИСТИЧКА ФОРМА ВО НАЦИОНАЛНИТЕ ПАРКОВИ НА РС МАКЕДОНИЈА

Tatjana Dimitrova; Slavi Dimitrov - TOURISM MANAGEMENT THROUGH PLANNING

DOCUMENTS AT REGIONAL AND LOCAL LEVEL.

Никола В. ДимИтров - РЕГИОНАЛЕН ПРЕГЛЕД НА ПЛАНИНСКИОТ ТУРИЗАМ ВО

РС МАКЕДОНИЈА..

Душица Матета Гигова; Елизабета Митева - ГЛОБАЛИЗАЦИЈАТА И ТУРИЗМОТ ВО

РЕПУБЛИКА СЕВЕРНА МАКЕДОНИЈА.

Dora Kabakchieva - ADDITIONAL VALUE END EFFECT OF DIGITALIZATION IN

TOURISM

Илија Закоски - УЛОГА НА ИНТЕРНЕТОТ ПРИ ИЗБОР НА ТУРИСТИЧКА

ДЕСТИНАЦИЈА И ОРГАНИЗАЦИЈА НА ТУРИСТИЧКО ПАТУВАЮЕ .

Dragan Tezanovik; Sanja Filipovic; Maja Banjak - COFFEE AS A SIGNIFICANCE

SEGMENT OF THE CATERING OFFER - CASE STUDY OF THE CITY NIŠ

Biljana Petrevska; Dajana Bjelajac; Bojan Djercan - DARK SKY TOURISM: PROSPECTS

AND CHALLENGES FOR NORTH MACEDONIA

Перпарим К'ахили - КЛИМАТСКИ И ХИДРОГРАФСКИ КАРАКТЕРИСТИКИ ВО

РАЗВОЈОТ НА ТУРИЗМОТ ВО РЕГИОНОТ ЈИЛАН

Дарко Мајхошев; Цане Котески - ЛИСТИ НА УНЕСКО ЗА ЗАШТИТА НА

СВЕТСКОТО НАСЛЕДСТВО СО ПОСЕБЕН ОСВРТ НА ЛИСТАТА НА СВЕТСКО

НАСЛЕДСТВО ВО ОПАСНОСТ

Monika Angeloska- Dichovska; Katerina Bojkovska; Elizabeta Tosheva - INNOVATION

STRATEGIES FOR YOUTH TOURISM AS A CONTIBUTION TO THE ECONOMIC

DEVELOPMENT OF THE WESTERN B ALKAN COUNTRIES.

Naser Bresa - VERMICA -TOURIST OASIS, CULTIVATOR AND SERVER OF TROUT

Арбен Халили; Мислим Зендели - АПИТУРИЗАМ КАКО НОВА ДИМЕНЗИЈА ЗА

ПАТУВАЮЕ НИЗ ШАР ПЛАНИНА.

Билјана Николовска - ПРЕДИЗВИЦИ И ИНОВАЦИИ НА МАКЕДОНСКИТЕ 
ТУРОПЕРАТОРИ СО ПОСЕБЕН ОСВРТ НА ПЕРИОДОТ ОД 2019 ДО 2021 ГОДИНА

Зоран НИКОЛОвсКИ - ОРГАНИЗАЦИЈА И КЕТЕРИНГ НА ДЕЛОВНИ НАСТАНИ НИЗ

ПРИЗМА НА МАКЕДОНСКИТЕ КЕТЕРИНГ КОМПАНИИ

Vanya Vasileva; Iliana Dimitrova - DEVELOPMENT OF GOLF TOURISM ON THE

NORTHERN BULGARIAN BLACK SEA COAST.

Васко Шутаров - ГАСТРОДИПЛОМАТИЈА ВО ВРЕМЕ НА ПАНДЕМИЈА

Velibor Tasevski - IMPACT OF THE COVID 19 PANDEMIC ON NUMBER OF

TOURISTS IN REPUBLIC OF N. MACEDONIA

Цане Котески; Александар Магдески - СОВРЕМЕНИ ФОРМИ НА МЕЃУНАРОДЕН

ТУРИЗАМ СО ПОСЕБЕН ОСВРТ НА ГРАДСКИОТ И ЕВЕНТ ТУРИЗМОТ. 344

Karlo Mac; Cvetan Kovac - THE IMPACT OF CRISIS ON THE SEASONALITY OF CROATIAN TOURISM AFTER 2000. 362

ЗлаТко ЈаковЛев - МЕНАЏМЕНТ НА АНИМАЦИЈАТА ВО ТУРИСТИЧКО УГОСТИТЕЛСКИТЕ ПРЕТПРИЈАТИЈА 370

Тања Ангелкова Петкова; Цветанка Ристова Магловска - ЗНАЧЕњЕТО НА ТУРИСТИЧКИТЕ АГЕНЦИИ ЗА РАЗВОЈ НА МАКЕДОНИЈА КАКО АТРАКТИВНА ТУРИСТИЧКА ДЕСТИНАЦИЈА. 379 
Четврта Меѓународна Научна Конференција ПРЕДИЗВИЦИТЕ ВО ТУРИЗМОТ И БИЗНИС ЛОГИСТИКАТА ВО 21 ВЕК »ISCTBL $2021 \ll$

Fourth International Scientific Conference

CHALLENGES OF TOURISM AND BUSINESS LOGISTICS IN THE 21ST CENTURY »ISCTBL 2021«264

UDK 338.483.12:930.85]:061.1UNESKO(100)

\title{
СОВРЕМЕНИ ФОРМИ НА МЕГ์УНАРОДЕН ТУРИЗАМ СО ПОСЕБЕН ОСВРТ НА ГРАДСКИОТ И ЕВЕНТ ТУРИЗМОТ
}

\author{
Цане Котески ${ }^{1}$ Александар Магдески ${ }^{2}$ \\ Проф.д-р Цане Котески,Универзитет „Гоце Делчев“ Штип,cane.koteski@ugd.edu.mk \\ м-р Александар Магдески,Универзитет „Гоце Делчев“ Штип aleksandar.magdeski@ yahoo.com
}

\begin{abstract}
Апстракт
Развојот на туризмот во градовите е важно истражувачко прашање во последните неколку декади. Интересот на истражувачите во областа на туризмот произлегува од напорите да се укаже на важноста на градовите како туристички дестинации со изразена мултифункционалност на просторот и ресурсите. Градскиот туризам е еден од иновативните начини за користење на постојната структура на ресурси за дизајнирање на нов туристички производ, што ќе им овозможи на градовите да бидат поконкурентни на меѓународниот туристичкиот пазар. Компаративните предности на градскиот туризам се рефлектираат во можноста на градовите да обезбедат соодветно искуство за различни туристички демографски профили и повеќе мотиви за патување. Покрај тоа, во споредба со другите видови туристички дестинации, во градовите влијанието на сезоната е многу помалку изразена, што ни укажува во текот на целата година и униформен прилив на туристи. Современите туристички трендови укажуваат на растечки интерес на туристите за пократки и почести одмори во текот на годината, што се реализираат во градовите на повидок т.н. City break патување. Таквата тенденција придонесува за раст на привлечноста на градовите како туристички дестинации, што дополнително се рефлектира во реализација на целите на голем број превозници на туристичката понуда. Предметот на истражување, со кое се занимава овој труд, е развој на градскиот туризам и евент туризмот во Република Македонија. Со цел да се има објективен и аналитички пристап кон предметот на истражување, извршена е детална анализа на постојната туристичка понуда на клучните играчи во развојот на градски туризам и на евент туризмот во Македонија.
\end{abstract}

Клучни зборови: градски туризам, евент туризам, City break, Република Македонија, управување, туристичка дестинација.

\begin{abstract}
The development of tourism in cities has been an important research issue for the last few years decade. The interest of researchers in the field of tourism stems from the efforts to point out the importance of cities as tourist destinations with a pronounced multifunctionality of space and resources. City tourism is one of the innovative ways to use the existing resource structure for designing a new tourism product, which will allow cities to be more competitive in the international tourism market. The comparative
\end{abstract}


advantages of City tourism are reflected in the ability of cities to provide an appropriate experience for different tourists, demographic profiles and multiple travel motives. In addition, compared to other types of tourist destinations, in cities the influence of the season is much less pronounced, which indicates a uniform year-round influx of tourists. Modern tourism trends indicate growing interest of tourists for shorter and more frequent vacations during the year, which are realized in the cities in sight, the City break travel. Such a tendency contributes to the growth of the attractiveness of cities as tourist destinations, which is additionally reflected in the realization of the goals of a large number of carriers of the tourist offer. The subject of research, which deals with this paper, is the development of City tourism and event tourism in the Republic of Macedonia. In order to have an objective and analytical approach to the subject of research, a detailed analysis of the existing tourist offer of key players in the development of City tourism is underway in Macedonia.

Key words: city tourism, event tourism, city break, Macedonia, management, tourist destination.

\section{Вовед}

Во современи деловни услови, кои се карактеризираат со значителни промени на меѓународниот туристички пазар и интензивна конкуренција помеѓу дестинациите, туризмот е многу динамичен и хетерогена услужна активност. Промените се забележуваат од страната на носителите на развој на туризмот во дестинациите, но и во однесувањето и потребите на туристите. Со проширувањето на туристичките патувања, дојде до промена на начинот на функционирање на носителите на развојот на туристичката активност. Од деценија во деценија, тие еволуирале во иновации на туристичкиот сектор (нискобуџетни авиокомпании, пакет зделки, франшизинг и други форми на договорни аранжмани, деловна активност на тур-оператори, компјутеризирани системи за резервации, зелен туризам, социјални мрежи како средство за промоција и комуникација со туристи итн.). Од аспект на туристичката побарувачка, постои тенденција на чести промени во однесувањето, мотивите, потребите и барањата на туристите. Туристите се едуцирани, многу информирани за понудата на дестинацијата и очекувааат одредена вредност за парите. Оттука, управувањето со дестинацијата и учесниците во синџирот на вредности во туризмот, се да се најдат начини за постојано подобрување на квалитетот на туристичките производи и нивната иновација, што создава основа за постигнување и задржување на конкурентни позиции на туристичкиот пазар. Популарноста на градовите како туристички дестинации и зголемената побарувачка за city break патувања се поврзани со низа фактори како што се: подобрување на квалитетот на услугите на аеродромите, достапност на дестинации по авион, ефтини летови, потоа инвестиции во други сегменти сообракајна инфраструктура (јавен превоз, пешачки зони) и туристичка надградба. Многу често туристите се одлучуваат за city break патувања што им овозможува автентично патување и за пократок период го запознаваат градот. Со оглед на времетраењето и активностите, ваквите патувања се многу интересни за туристите. Исто така, сложената структура на туристичките објекти во градовите и исполнувањето на слободното време влијаат на туристите повторно да посетат одреден град, што придонесува поголема туристичка лојалност кон дестинацијата. Понудата за градски туризам не е наменета исклучиво за туристи, но и на жителите, кои можат да имаат корист во форма на вработување, но исто така имаат можност да ги користат туристички услуги.

\section{Предмет на истражување}

Предмет на истражување во овој труд е градскиот туризам, улогата на градовите во развојот на туристичката индустрија. Предметот на истражување е тесно поврзан со научните области на економија и менаџментот (поточно дефинирани во управувањето со туристичките дестинации). На разгледувањето на предметот на истражување се пристапи со примена на теоретската анализа, која 
се заснова на систематско претставување на знаењето од достапната домашна и странска стручна литература, книги, прирачници, зборници и други извори, односно за употреба на секундарни извори податоци со оглед на тоа дека ова е тема што се уште не е доволно истражена во науката на национално ниво, најголем дел од литературата, што беше искористена за дефинирање на теоретската рамка, доаѓa од меѓународно признати списанија од областа на туризмот и управувањето. Теоретскиот пристап кон предметот на истражување дава сигурна основа за дефинирање на анкетни прашалници и спроведување емпириско истражување за тестирање на хипотетички прашања.

\section{Цели на истражувањето}

Трудот поставува цели во согласност со степенот на нивната важност за постигнување на одредено научен и социјален придонес. Главната цел на истражувањето е да се укаже на важноста и мултифункционалност на градовите како туристички дестинации со цел проширување на постојните теоретски и емпириско знаење за градскиот туризам со посебен акцент на неговото значење за туризмот и економија на Македонија. Научната цел е научниот опис на градскиот туризам, неговите манифестации и специфики на неговиот развој со посебен акцент на важноста на градскиот туризам за Република Македонија и нејзината туристичка индустрија. Трудот има за цел систематизирање и поврзување претходни истражувања и знаења за туризмот во градовите, нагласувајќи мултидисциплинарност.

\section{Методологија на истражување}

Комплексноста на предметот на истражување бара примена на соодветно истражување инструментариум, кој се состои од соодветни и сигурни методи и техники на истражување. Имајќи го предвид големиот број на елементи и врски што постојат во дефинираното поле на истражување, како и поради присуството на влијанието на различните фактори врз развојот на градскиот туризам и барањата на туристичката побарувачка, постоењето и работењето на голем број учесници во развојот на градскиот туризам и сл, утврдено е дека станува збор за сложена, динамична и повеќеслојна област на истражување.Заради собирање на изјави, искуства и ставови, методот на испитување беше користен во трудот, односно анкети. За таа цел, беа формирани два анкетни прашалници. Со цел да се соберат податоци за степенот на задоволство од квалитетот на понудата на градски туризам. Исто така употребен е и делфи методот кој е спроведен помеѓу клучните учесници при конструирање на домашната стратегија за туризам и организирање на туристичката понуда во градовите на Р. Македонија кој имаат потенцијал да станат подобра туристичка дестинација и со тоа да се зајакни економијата во Р. Македонија.

Првиот прашалник е наменет за одреден број на туристи кои претстојувале на некој евенти и манифестации во туристичките дестинации на Р. Македонија.

Вториот Прашалникот беше дистрибуиран до вработените во туристичките компании (хотели, туристички агенции, транспортни компании и сл.), компании за комплементарни активности, јавен сектор ( туристички организации на национално и локално ниво и сл.) државен сектор како и деловните здруженија од областа на туризмот.

\section{Очекуван научен придонес}

Овој труд ќе овозможи да се разберат постојните теоретски знаења за улогата и важноста на формите на меѓународниот туризам. Од друга страна, достапноста на богата и разновидна научна и стручна литература во оваа област претставува важен предуслов за квалитетна и сеопфатна теоретска анализа. Очекувани резултати истражувањето вклучува при потврдување на тврдењето за важноста на градовите за целата туристичка индустрија и систематска и концизна анализа на 
ставовите на испитаниците за туристичката понуда на градовите од Република Македонија што може да се искористи за дефинирање на упатства за иден развој. Научниот придонес треба да се рефлектира во поврзаноста на теоретското знаење и резултатите од емпириското истражување како и ставови на разни интересни групи, кои се вклучени во развојот, пласирањето и промовирањето на понудата на градски туризам, и туристи, кои ја консумираат понудата за градски туризам за време на нивниот престој во градот. Заклучоците од истражувањето ќе бидат дефинирани во согласност со утврдениот предмет на истражувањето. Методолошката рамка на истражување во овој труд е поставена врз основа на широко достапен научен и стручен материјал, кој е исто така основа за поставување на концептот на емпириско истражување. Добиените резултати од емпириското истражување ќе бидат основа за дефинирање на упатствата, кои можат да им помогнат на имателите на туристичката понуда на градовите. Актуелноста на темата, што е предмет на истражување во трудот, е од голема важност за примена во идните истражувања.

\section{Градски туризам}

Градскиот туризам е значајно и карактеристично поле на истражување, особено во текот на 90тите години на минатиот век. ${ }^{1}$ Поинтензивно истражување на концептот и карактеристиките се укажува за постоењето на поголем број дефиниции за градскиот туризам, како и неконзистентност на ставовите на истражувачите за општо прифатените дефиниции. Комплексноста на истражувањето и дефинирањето на концептот на градски туризам е условена од поголем број фактори, почнувајќи од големината на градот, неговата историја наследство, морфологија, животна средина, локацијата и сликата. ${ }^{2}$ Покрај карактеристиките на градот, неопходно е истражувањето за градскиот туризам од аспект на низа научни дисциплини и е условен од фактот дека градскиот туризам е неразделен дел од социјалното, просторно, економско и технолошко опкружување, како и урбанизацијата и делувањето на глобализација. ${ }^{3}$ Развојот на туризмот во градовите влијае на сите сегменти на функционирање на градот поради што резултира во комплексни врски помеѓу туризмот и другите форми на деловно работење во градот. Околу тоа, туризмот влијае не само на економскиот развој на градот, туку и на неговиот културен и социјален развој. Според Перош ${ }^{4}$, градскиот туризам поставува две релативно спротивни барања за туризам дестинации. Од една страна, тоа е универзалност на туристичкиот производ во однос на неговата прифаќањето на глобално ниво, од друга страна, се оригиналност, автентичност и локалитет. Европската комисија го толкува градскиот туризам како збир на низа активности, вклучително и:

- Слободен туризам, кој е поврзан со одредени сегменти на урбаните области;

- Деловен туризам, кој е тесно поврзан со економската, социјалната и културната моќ градови, и

- Конгресен туризам, кој е поврзан со објекти што се достапни и влијаат на имиџот на градовите.

\section{Градовите како туристички дестинации}

Терминот дестинација потекнува од латинскиот збор destinatio, што значи дестинација или цел. Терминот одморалиште често се споменува во литературата, што се толкува на ист начин контекст, како и туристичка дестинација. Сепак, Prideaux ${ }^{5}$ истакнува дека идентификацијата е

1 Pearce, D. (2001). An Integrative Framework for Urban Tourism Research. Annals of Tourism Research, 28 (4), p. 926.58

2 Cosma, S. A. (2012). Measurement Tourism Performance of Urban Destinations. Journal of Travel and Tourism Research (Online), 12 (1), p. 51

${ }^{3}$ Cave, J. \& Jolliffe, L. (2012).Urban Tourism: The Key Concepts. Robinson, P. (Ed.) London: Routledge, p. 268

4 Peroš, L. (2013). Affirmation of cultural identity tourism destination through city break travelling-Zadar city example. The Third International Scientific Congress-Biennale: Icon Best 2013, Skopje, Makedonija, 5-7 August 2013, p. 226.

${ }^{5}$ Prideaux. B. (2009). Resort Destinations - Evolution, Management and Development. Elsevier Ltd, p. 10. 
вообичаена поимот дестинација и одморалиште е резултат на употребата на споменатите термини во туристичката индустрија и од од креаторите на туристичката политика. Во европски контекст, одморалиште значи просторна целина, во кои туризмот е главна дејност. Основата за подлабока анализа на концептот на дестинација е туристичко место, односно место за одмор, кое привлекува голем број туристи и на кое им обезбедува туризам со посебни карактеристики така што приходот остварен врз основа на туризам игра важна улога во неговото функционирање. Бидејќи одморалиштето може да се дефинира во потесна смисла како хотелски комплекс, што на едно место ги нуди сите потребни услуги за задоволување на потребите на туристите до дефиницијата, што подразбира пошироки туристички дестинации, кои можат да вклучуваат градови, концептот на дестинација е поширок од поимот одморалиште.

\section{Туристичка понуда на градовите}

Со цел објективно да се анализира градскиот туризам, потребно е да се прошират истражувањата со тоа да се разгледаат клучни карактеристики на туристичката понуда и туристичката побарувачка. Туристичката понуда за градски туризам составена е од привлечни, комуникативни и рецептивни фактори. Од друга страна, при создавањето, промоцијата и пласманот на понудата за градски туризам вклучува различни субјекти од туристичката економија, кои обезбедуваат интегриран туристички производ за задоволување на потребите на туристите. Високата концентрацијата на туристи во градовите укажува на потребата да се испита мотивацијата на туристите за посета на градови како и начини да го поминувате слободното време додека патувате. Туристичката побарувачката на градовите е многу специфична и се рефлектира во повеќе причини за посетата, како резултат на можноста на градот за своја сопственост со единствена понуда да се обезбедат сите потребни услуги и установи за задоволување на потребите на туристите. Туристичката понуда на градовите е многу специфична поради фактот што вклучува голем број елементи и да ги користат истите ресурси како и другите форми на градски туризам. Важна карактеристика на градот е да туризмот се рефлектира во фактот дека одредени форми на овој туризам се посебни форми на туризам. Сепак, одредени форми на туризам може да се гледаат како дел од туристичката понуда на градовите, со што се дава комплексен карактер на туризмот во градовите. Туристичката понуда на градовите значително се разликува од понудите на други видови дестинации за пократок престој на туристите во градовите. Исто така е важно разликата да се рефлектира во бројот на одлуки што туристите треба да ги донесат за пократок временски период какви услуги ќе користи за време на престојот во градовите. Во оваа смисла, комплексноста на понудата на градовите не произлегуваат единствено од постоењето на голем број елементи, предмети и содржини од туристички карактер, но и од неопходност за воспоставување координација и интензивна соработка носители на туристичката понуда. Туристичката понуда на градски туризам е составена од голем број елементи, од кои основната е функција што обезбедува целосно задоволство на туристите во градот. Јансен-Вербеке ${ }^{6}$ се смета за еден од првите теоретичари, кои се обидоа да ги класифицираат елементите на туристичката понуда на градовите идентификување на внатрешноста на градот како место на активност што ги има потребните елементи за трошење на слободното време на туристите. Класификација, дефинирана од Јансен-Вербеке подразбира примарни, секундарни и дополнителни елементи на градскиот туризам.

Обидувајќи се да формулираат класификација на туристичките атракции во градот, истакнаа Шовал и Равел ${ }^{7}$ дека историското јадро на градот и главните културни институции (музеи, театри, концертни сали, итн.), главни деловни центри, улици со продавници, градски паркови се главните

6 Jansen-Verbeke, M. (1986). Inner-City Tourism: Resources, Tourists and Promoters. Annals of Tourism Research, 13 (1), p. 85.

7 Shoval, N. \& Raveh, A. (2004). Categorization of tourist attractions and the modeling of tourist cities: based on the co-plot method of multivariate analysis. Tourism Management, 25 (6), p. 741 
атракции на градскиот туризам, така што овие објекти и објекти најчесто се концентрирани во центарот на градот заедно со сместувачки капацитети, кои првично биле наменети за туристи. Нивниот став се заснова на фактот дека клучните атракции се наоѓaат во самиот центар на градот и дека тоа се елементите што го сочинуваат најголем дел од туристичката понуда. Постоење на просторна близина до атракции и сместувачки капацитети укажува на голема концентрација на туристи во центарот на градот.

Табела 1. Компоненти на производи за градски туризам

\begin{tabular}{|c|c|c|}
\hline Елементи & Услуги /Настани & Имиџ \\
\hline Интересна архитектура & Фестивали,паради & Возбудлив \\
\hline Историски градби & Културни манифестации & Историски \\
\hline Културни објекти & Претстави & Зачудувачки \\
\hline Цркви, храмови, џамии & Спортови & Пријателски \\
\hline $\begin{array}{l}\text { Единствен } \\
\text { амбиент }\end{array}$ & Тури низ градот & Убав \\
\hline $\begin{array}{l}\text { Јавни паркови } \\
\text { плоштади }\end{array}$ & Биоскоп & Уметнички \\
\hline $\begin{array}{l}\text { Патеки за пешачење, } \\
\text { канали }\end{array}$ & Капацитети за сместување & Етнички \\
\hline Планини и реки & Исхрана & Духовен \\
\hline Споменици & Забава & Фамилијарна забава \\
\hline Транспортен систем & & \\
\hline
\end{tabular}

Поаѓајќи од фактот дека елементите на туристичкиот производ на градот влијаат врз создавањето на имиџот на градот како туристички дестинации, Колб ${ }^{8}$ наведува широка класификација на овие елементи. Во согласност со тим, елементите на производите, услугите на градскиот туризам и сликата за градот претставуваат значаен сегмент на искуства што туристите ги стекнуваат за време на нивниот престој во градот (Табела 1). Создавање производ во градскиот туризам бара континуирано подобрување на истиот со цел да се окупира и одржува конкурентни позиции како и учество на голем број субјекти, кои обезбедуваат услуги на туристите во градот.

\section{Форми на градски туризам}

Во овој дел од трудот се дефинирани две тематски под-поделби, во рамките на кои се анализира City break патувањата и основни форми на туризам што се развиваат во градовите. Кратки патувања до градовите, (City break патувања), во споредба со другите форми на туризам, ce специфични по должина задржување на туристите во дестинацијата и начинот на организирање на самото патување. Имајќи предвид дека мотивите за City break патувањата се повеќекратни и дека понудата на оваа форма на туризам вклучува голем број на туристичките ресурси и содржини, кои постојат во градовите, издвоени се и анализирани основните форми на туризам во градовите, имено: културен, деловен туризам и евент-туризам.

\section{Кратки патувања во градовите - Патувања низ градот}

City break патувањата се специфичен вид пократки туристички патувања кои преовладуваат фокусирани на разгледување. Клучните карактеристики на City break патувањата се: според карактерот на празникот и краткиот период на престој во градот. Во градот се случуваат City break патувања кои преминуваат во една од најважните форми на туризам во светот, која нема сезонски 
карактер. Ова форма на патување се прошири многу брзо, така што денес голем број луѓе од целиот свет одат на викенд патувања во европските градови и пошироко. Трендот е пократок, но почестите патувања претставени при посета на градските дестинации, чии атракции се интересни за туристите. Фактот дека можат да патуваат дури и кога имаат малку слободно време, како и фактот дека имаат такви аранжмани и прифатлива цена укажува на тоа дека туристите многу често се одлучуваат за ваков вид патувања.

\section{Концептот и карактеристиките на city break патувањето}

City break патувањата се препознаени како форма на туристичко патување во последните децении во експанзија. Тие претставуваат ветувачки туристички производ за градовите, чиј потенцијал се рефлектира во целогодишен прилив на туристи и можности за комбинирање на различни туристички производи во единствена целина и како таква им се нуди на туристите. Овој вид патување најчесто се нарекува кратко градски одмор. City break патувањето значи кратко патување на одмор до еден град што не вклучува ноќевања на друга дестинација за време на патувањето. Слично на ова, Дан, Фланаган и Бакли ${ }^{9}$ сугерираат дека, според горенаведената дефиниција, тоа е можно доколку ги поделите туристите на оние кои патуваат само во еден град и оние туристи кои го посетуваат градот во рамките на подолги патувања. Според Чартерина и Апарисиу ${ }^{10}$, City break патувањата се кратки патувања, кои најчесто се реализираат со користење на воздушен транспорт на пократки рути од соседните земји или блиски области. За оваа форма на патување, туристите обично ја одбиваат главната туристичка сезона, односно најчесто за време на важни настани или прослави празници (Нова Година, Божиќ, итн.) се фокусирани на запознавање со културните наследства заедно со нив соодветна забавна содржина. Важен предуслов за реализација на овие патувања е постоењето аеродроми и добри врски со летови до градовите, до кои одат туристите. Главните карактеристики на city break дестинациите се рефлектираат во:

- Пократко патување, обично трае меѓу една и три ноќи.

- Дестинацијата се наоѓа во блиска, многу често соседна земја.

- Тоа е додаток на главниот празник во текот на годината.

- Флексибилност при одредување на времето на патување.

• Туристите патуваат во парови или како дел од група пријатели.

\section{Фактори на City break патувањата}

City break патувањата се особено карактеристични за европските дестинации. Растот на интересот на туристите во Европа за овој вид одмор произлегува од повеќе причини. Прво, расте достапност на нискобуџетни авиокомпании и летови со ниска цена за пократки патувања од точка до точките многу влијаат на туристите да се одлучат за годишен одмор. Така, голем број градските дестинации стануваат достапни за туристите. Од друга страна, изразена е тенденцијата на Европејците да се одлучат за почести, но пократки патувања. Тенденцијата на раст на бројот на пократки патувања тоа е условено од поголем фонд на слободно време и фактот дека луѓето се ослободени од деловно работење обврска за време на големи празници во текот на годината. Релативно ниските патни трошоци се последица фактот дека туристичкиот сообраќај е претежно интрарегионален по природа, односно дека тие емитуваат и рецептивни области релативно блиску една до друга. Во време на криза, луѓето се под повисоки притисок и сакаат да го ослободат стресот трошејќи квалитетно слободно време.

9 Dunne, G., Flanagan, S. \& Buckley, J. (2011). Towards a decision making model for city break travel. International Journal of Culture, Tourism and Hospitality Research, 5 (2), p. 159.

10 Charterina, J. \& Aparicio, G. (2015). A comparison of antecedents of satisfaction in city break traveling. Revista Española de Investigación En Marketing ESIC, 19 (2), p. 73. 
Ориентацијата кон градовите следеше поради желбата на луѓето да ги задоволат своите потреби за купување, забава и одмор во урбана средина. Затоа, луѓето го доживуваат градот како дестинација само по себе, а не како транзитна точка за време на патување до друга дестинација. ${ }^{11}$

\section{Карактеристики на пазарот за City break патувањата}

Градовите се важни центри на политички, економски, културни и други настани. Динамиката на животот во градот и неговиот постојан фокус на подобрување на квалитетот содржината за туристите го условува растот на бројот на туристи во градовите. Специфичноста на пазарот за City break патувањата е охрабрено од голема концентрација на туристи од различни патни потреби и мотиви, а ова го условува постојаниот фокус на управување со дестинацијата кон постојано подобрување туристички понуди со цел да ги задоволат барањата на туристите и да постигнат конкурентна позиција на туристичкиот пазар. Независната организација на патувања е последица на појавата на нискобуџетни воздушни патувања компании, што овозможија пониски цени на услугите за превоз и значително побрзо патување до крајните дестинации. Покрај тоа, можноста за резервација преку Интернет ги направи поедноставни и поевтини набавката на туристички услуги. Барање да се развие модел на донесување одлуки за преземање на City break патувањата, Дан, Фланаган и Бакли ${ }^{12}$ ги дефинираа факторите на push and pull, кои влијаат за донесување туристички одлуки за City break патувањата. Push фактори се однесуваат на желбата на луѓето да да избега од секојдневните обврски и да се занимава со некои други активности, како и желбата за остварување социјални контакти. Во овој случај, активностите со кои се вклучуваат туристите за време на City break патувањата се разгледување на градот, посета на угостителски објекти, посета на настани итн.

Pull мотиви се однесуваат на атрибутите на градовите, кои привлекуваат туристи со нивната привлечност, уникатност и квалитет.

\section{Основни форми на туризам во градовите}

Во овој дел од трудот се анализираат клучните форми на туризам, кои се развиваат во градовите: културолошки туризам, деловен туризам и евент туризам.

\section{Културен туризам}

Многу често се претставени патувања мотивирани од желба да се запознаат културното наследство на туристичкиот пазар. Предмет на интерес на туристите е културното наследство, и материјално и од нематеријална природа. Културата како причина за патување придонесува за раст на пазарниот удел на туристи во вкупниот туристички сообраќај, а со тоа и популаризација на оваа форма на туризам. Растење на важноста на културниот туризам може да се толкува на два начина. Прво, луѓе, во постојани услови промена, тие се обидуваат да се поврзат со минатото време со цел да стекнат чувство на припадност и стабилност. Второ, очекуваното траење на животот е многу подолго и луѓето многу често патуваат на далечни места. Постарата популација стана значаен дел од туристичкото побарување, што гледа можност да се посетат одредени културни настани, потсетува на минатото. Значајна предност на културниот туризам што се рефлектира во поврзаноста со другите видови туризам (религиозен, настан туризам, итн.), кои се комбинирани различни активности за туристите во една целина. Исто така, развој на културниот туризам овозможува дестинацијата да постигне позитивни резултати преку валоризација и промоција на нејзиното културно наследство економски ефекти притоа почитувајќи го принципот

${ }^{11}$ Rabotić, B., (2013). City break putovanja - selektivni oblik turizma. Časopis Hotel Link, 21-22, str. 584.

12 Dunne, G., Flanagan, S. \& Buckley, J. (2011). Towards a decision making model for city break travel. International Journal of Culture, Tourism and Hospitality Research, 5 (2), 158-172. 
на одржливост. Културниот туризам може да се гледа од аспект на желбата и потребата на туристите да го запознаат културниот наследството на одредено место со цел проширување на претходното знаење за неговата култура и традиција. Културниот туризам е врска помеѓу две појави што се важни за човештвото. Тоа се културата, како збир на културни вредности и туризмот, што придонесува за комерцијализација на културното наследство на одредена област.

\section{Деловен туризам}

Како една од најстарите форми на патување, деловниот туризам станува важен за подобрувањето на економиите на локално и регионално ниво, како и дел од туристичкиот сектор со голем потенцијал за иден развој. Според Светскиот совет за туризам и патување(WTTC) ${ }^{13}$, учеството на деловните патувања во светскиот БДП во патувањата и туризмот беше 21,5\% во 2018 година. Вкупната сума на пари потрошени на службени патувања во во таа година изнесуваше 1,228 милијарди долари. Според проекциите за 2019 година, стапката на раст трошењето за деловни патувања е 3\%, односно потрошувачката се очекува да биде 1.265,4 милијарди долари. Според долгорочната проекција, се очекува стапка на раст на трошењето за деловни активности патувањето ќе биде 3,2\% во 2029 година, односно 1,735,1 ќе бидат потрошени за службени патувања милијарди долари. Податоците го поддржуваат фактот дека ова е ветувачка туристичка дестинација производ што треба да го развиваат дестинациите за да се постигне долгорочна конкурентна позиција на туристички пазар.

\section{Туристички евенти}

Евент туризмот е многу популарен вид на туризам за оние туристи кои се за останување во туристичката дестинација со пократко траење и чиј мотив за патувањето е токму присуството на одреден евент. Туристичките евенти претставуваат значителен сегмент од туристичката понуда во светот. Евентот или настанот се дефинира како настан што се случува на одредено место и под посебен пакет на околности што претставува значаен феномен. ${ }^{14}$ Примарната функција на настаните е многу често концентрирана на промоција на културата, традицијата, одликите и автентичните вредности на туристичката дестинација.

\section{Концепт за Smart туризам}

Развојот на информатичките технологии и интернетот е значително променет и подобрен во функционирањето на современото општество. Секојдневниот живот на човештвото е незамислив без примена на интернет. Бројот на корисници на Интернет во 2018 година беше 3,9 милијарди луѓe или $51,2 \%$ светска популација. ${ }^{15}$ Покрај тоа, проширувањето на паметните телефони им овозможува на луѓето да течат да бидат присутни цел ден на Интернет и разни социјални мрежи на кои споделуваат содржина и комуницираат со други луѓе. На глобално ниво, најголемиот дел од светската популација користи Интернет секој ден како средство за купување, комуникација, споделување на разни содржини,собирање информации и со тоа заштеда на време и пари, но и забава со употреба на разни страници, апликации и социјални мрежи. Тие се неизбежно технолошки достигнувањата го сменија денешниот начин на живот, но исто така и начинот на работа на големите системи. Да бидеш ефикасен и конкурентен, компаниите континуирано ги

13 WTTC. (2019). Travel \& tourism economic impact 2019 world. Dostupno na: https://www.wttc.org//media/files/reports/economic-impact-research/regions-2019/world2019.pdf, (datum pristupa 20.04.2019.), p. 6.

14 Getz, D. (2007). Event studies: theory, research and policy for planned events. Butterworth Heinemann, Oxford, p. 18.

15 International Communication Union, https://www.itu.int/en/ITU-D/Statistics/Pages/stat/default.aspx, (datum pristupa 28.01.2019.) 
иновираат своите напредни деловни операции информациони системи и софтверски решенија. Информациските и комуникациските технологии имаат значително влијание врз развојот на економијата, вклучително и туризмот како растечка економска активност.

\section{Паметни градови (Smart cities)}

Концептот за паметни градови еволуираше кон крајот на 90 -тите години на минатиот век кога тие се случија. Научната заедница, индустријата и владите на голем број земји покажаа заеднички интерес за трансформација на градовите во одржливи простори засновани врз иновации. ${ }^{16}$ Бројот на научни публикациите и студиите за градовите драматично се зголемија од 2011 година. Таков тренд е поврзан со појавата на паметни градски проекти во Европската унија. Значителен интерес од различниот субјект и организацијата потекнуваа од стремежот да се решат клучните проблеми на современиот живот човекот во урбаните средини. Голема густина на население, загадувањето непланирана градба, тесниот сообраќаен метеж и други проблеми им наложија на властите да размислат за откритието на уникатно решение, кое би го подобрило функционирањето на градот како комплексен ентитет. Терминот паметните градови (smart cities) ce користат, со текот на времето, во различни контексти. Првично беше навикнато на опишување како дигитален град, подоцна развиен во социјално инклузивен град, кој нуди подобар квалитет на живот засновано на употреба на технолошки иновации. Бери и Гласер ${ }^{17}$ ја истакнуваат важноста на човечкиот капитал и образование за развој на паметни градови со објаснување дека најбрзиот урбан развојот го постигнуваат градови во кои учеството на образована работна сила е големо. Сепак, Мејер и Боливар ${ }^{18}$ укажуваат на постоење на три концепти за толкување на дефиницијата за Smart city: паметни градови како градови кои користат паметни технологии (технолошки фокус), паметни градови како градови со паметни луѓе (фокус на човечки ресурси) и паметни градови како градови чиј развој се заснова на соработка на различни актери (фокус на управување). Важен аспект дефинирање на концептот на паметни градови е еколошки. ${ }^{19}$ Поради честите еколошки проблеми во градови, потребно е да се анализираат иновативните форми на урбан развој од аспект на заштитата на животните средини со цел да се избегнат еколошки катастрофи и да се наруши животот на луѓето во градовите. Значи, под Smart city се смета град кој не ја загадува животната средина и не ја загадува и го загрозува функционирањето на самиот урбан простор, но кој користи обновливи извори на енергија.

Според Караглио, Дел Бо и Никамп, заеднички карактеристики на паметните градови се рефлектираат во следново: ${ }^{20}$

- Користење на мрежна инфраструктура за подобрување на економската и политичката ефикасност и социјален, културен и урбан развој, каде што терминот инфраструктура се однесува на услуги, сместување, простории за одмор и сл., како и во ИТ секторот (мобилни и фиксни телефони, телевизии, компјутер мрежи, е-трговија, интернет услуги и сл.).

- Акцентот е ставен на моделот на деловен урбан развој. Иако постојат спротивни ставови, паметни се наоѓаат градовите, кои се потпираат на економијата како клучен столб на урбаниот развој ниво на задоволително социо-економско работење.

\footnotetext{
16 Anthopoulos, L. (2015). Defining smart city architecture for sustainability. U: Tampouris, E. Et al. (Eds). Proceedings of the 14th IFIP Electronic Government (EGOV) and 7th Electronic Participation (ePart) Conference 2015, 30 August - 2 September, 2015, Thessaloniki, Greece,IOS Press, Amsterdam, p. 140

17 Berry, C. R. \& Glaeser, E.L. (2005). The divergence of human capital levels across cities. Papers in Regional Science, 84 (3), p. 438.

18 Meijer, A. \& Bolivar, R. P.M. (2016). Governing the smart city: a reviewof the literature on smart urbangovernance. International Review of Administrative Sciences, 82 (2), p. 396.

19 Lazaroiu, G. C. \& Roscia, M. (2012). Definition methodology for the smart cities model. Energy, 47 (1), 326332.

${ }^{20}$ Caragliu, A., Del Bo, C. \& Nijkamp, P. (2011). Smart cities in Europe. Journal of urban technology, 18 (2), p. 47-48
} 
- Ориентација кон постигнување социјална инклузија на жителите на градот во јавниот систем. Таков овој тренд ги охрабрува истражувачите и креаторите на политики да го решат клучното прашање на капиталот урбан раст, односно степенот до кој сите социјални класи имаат корист од технологијата развој?

• Клучната улога на високата технологија и креативните индустрии во долгорочниот урбан раст.

За развој на градовите, креативни занимања се исто така важни, според кои компаниите се ориентирани. Креативниот капитал ги одредува, охрабрува и зајакнува трендовите на миграција на квалификувана работна сила. Од друга страна, присуството на креативна и квалификувана работна сила не гарантира поволни перформанси на:

- Луѓето во паметните градови треба да ја користат технологијата за да имаат корист од неа.

- Социјалната и еколошката одржливост е основна компонента на паметните градови. Во свет на сиромашни ресурси, урбаниот развој се заснова на туризам и употреба на природни ресурси. Фондацијата успешен урбан развој е за одговорно користење на обновливи извори на енергија и ресурси. Постоењето на различни дефиниции и аспекти на анализата на паметниот град укажува на значајно репрезентација на овој концепт како предмет на истражување. Од друга страна, сѐ уште не е утврдена согласноста на авторот во врска со општото прифаќање на одредена дефиниција за паметни градови.

\section{Компоненти и димензии на Smart city}

Smart citis опфаќаат одредени компоненти и димензии, кои го овозможуваат нормалното функционирање на градот и неговиот развој заснован на информациони системи и други технолошки достигнувања. Компонентите и димензиите на паметниот град се разликуваат поинаку во литературата во зависност од аголот на набудување на истражувачот. Една од отежнувачките околности при дефинирање на клучните компоненти и димензии е комплексноста на управувањето со Smart city и неговиот развој. Испитување на можностите за развој на Сингапур, како интелигентен остров, и примена на информации технологија во својот развој, Махизнан е клучна димензија на паметниот град идентификувани: ${ }^{21}$ ИТ образование, ИТ инфраструктура, ИТ економија и квалитет на живот. Иако оваа класификацијата ја нагласува важноста на примената на информатичките технологии во важни сегменти функционирање на градот, како што е случај со образованието, димензијата на паметните градови е потребно е да се разгледа од аспект на клучните проблеми што се јавуваат во нивниот развој. Бидејќи радикални економски и технолошки промени, градовите се соочуваат со растечка конкуренција инвеститори, туристи, квалификувана работна сила и меѓународни настани. Значи градовите мора да спроведат стратешки инструменти за да обезбедат релевантни капацитети и идентификувани стратешки проекти за управување со урбанистички развој на ефикасен и конкурентен начин. Поаѓајќ од фактот дека е потребно да се искористи целата расположива технологија за развој на паметен град и ресурсите на интелигентен и координиран начин, Барионуево, Бероне и Рикарт се клучни димензиите на паметниот град дефинираа пет типа на капитал, кои придонесуваат за интелигенцијата на градот: ${ }^{22}$ економски (БДП, јачина на секторот, меѓународни трансакции, странски инвестиции), човечки (талент, иновации, креативност, образование), социјални (традиција, навики, религии, семејство), еколошки (енергетска политика, управување со отпад и вода, пејзаж) и институционален капитал (вклучување) население, раководни тела, избори). Еден начин за емпириско идентификување на димензиите на паметен град е преку проект наречен

${ }^{21}$ Mahizhnan, A. (1999). Smart cities: the Singapore case. Cities, 16 (1), p. 14-17.

${ }^{22}$ Barrionuevo, J. M., Berrone, P. \& Ricart, J. E. (2012). Smart cities, sustainable progress. IESE Insight, 14 (14), p. 51. 
Паметни градови-Рангирање на европски средни градови, што се реализира до Центар за регионални науки при Виенскиот универзитет за технологија, Катедра за географија Универзитет во Љубљана и институт за истражување ОТБ за домување, урбани студии и студии мобилност на Технолошкиот универзитет во Делфт.

Табела 2. Карактеристики и фактори на паметните градови

\begin{tabular}{|l|l|}
\hline Паметна економија(конкурентност) & Паметни луѓе(друштвен и човечки капитал) \\
\hline Пновативни дух & Ниво на квалификација \\
Претприемништво & Склоност кон доживотно учење \\
Продуктивност и заштитни знаци & Друштвено и етничко заедништво \\
Флексибилност на пазарот на трудот & Флексибилност \\
Интернационално позиционирање & Креативност \\
Способност трансформација & Космополитанизам / отворен ум \\
& Учество во јавниот живот \\
\hline Паметно управување (соработка) & \\
\hline Учество во донесување на одлуки & Паметна мобилност (Транспорт и икт) \\
Јавни и друштвени услуги & Локален пристап \\
Транспаретност при работењето на владата & Интернационален пристап \\
Политички стратегии и преспекиви & Достапност икт инфрастукура \\
\hline Паметна околина (природни ресурси) & Одржлив,иновативен и безбеден систем за транспорт \\
\hline Атрактивност на природни ресурси & Паметен начин на живот (квалитет на живот) \\
Загадување & Здрави услови за живот \\
Заштита на животна средина & Културни објекти \\
одржливо управување со ресурсите & Индивидуална безбедност \\
& Квалитет на домување \\
& Услови за образование \\
& Туристички атракции \\
\hline
\end{tabular}

Табелата 2 покажува шест карактеристики на паметните градови, како и факторите што ги сочинуваат тие карактеристики. Со цел да се рангираат градовите, секој од факторите е поделен на голем број индикатори. Паметната економија вклучува 7 фактори, кои се проценуваат врз основа на 12 индикатори, од кои се значајни: стапка на вработеност, број на патенти по глава на жител, број на новоотворени компании, број на компании со седиште во градот, БДП по глава на жител, итн. Во рамките на паметните луѓе, вклучени се 7 фактори, кои се проценуваат врз основа на 15 индикатори, меѓу кои се: значењето градот како центар на знаење, нивото на квалификација на населението, афинитети според концептот на доживотно учење учење, познавање странски јазици и сл. Паметното управување вклучува 4 фактори, кои се проценуваат врз основа на 9 индикатори: политичка активност на населението, број на претставници на локалната самоуправа по глава на жител население, учество на локалното население во донесувањето одлуки, задоволство од квалитетот на образованието систем, општински трошоци по глава на жител, итн. Паметната мобилност опфаќа 4 фактори, соодветно 9 индикатори, кои вклучуваат: задоволство од квалитетот на јавниот превоз, достапност на компјутерите во домаќинства, меѓународна пристапност, безбедност во транспортот итн. Паметна околина вклучува 4 фактори, кои се фокусирани првенствено на зачувување на природата и нејзините ресурси и се проценуваат 9 индикатори: број на сончеви часови во текот на годината, загадување, ефикасно користење на вода и електрична енергија и сл. 


\section{Концептот на паметни туристички дестинации}

Концептот на паметни туристички дестинации произлезе од концептот на паметни градови. ${ }^{23}$ Со растечката конкуренција и појавата на нови привлечни дестинации, туристичките дестинации започнаа да ги прилагодуваат моделите на управување и креирање туристички понуди за развој на современи информатички технологии. Примена на принципот паметен развојот во туристичките дестинации имплицира дека дестинациите мора да поврзуваат голем број заинтересирани страни преку динамична платформа, која се базира на информатичката технологија во со цел размена на информации за туристичките активности со цел подобрување на процесот на посвојување одлука. За да станат паметни, туристичките дестинации мора да создадат средина, што е вмрежана и поддржана од паметни апликации. Вториот чекор вклучува обезбедување карактеристични туристички производи и услуги со цел да се подобри конкурентноста и одржливоста туристички дестинации. Воведување на современи информатички технологии во концептот на паметни дестинацијата има двојна улога. Прво, тоа овозможува создавање на целокупно туристичко искуство и сите потребни услуги за туристите, додека од друга страна обезбедуваат разни туристи компаниите да соработуваат и да комуницираат едни со други. Туристичката дестинација може да биде паметна дестинација доколку користи технолошка инфраструктура за:

1) подобрување на туристичкото искуство и обезбеди персонализирана услуга за туристите, кои ја посетуваат дестинацијата и

2) го зајакнаа процесот управување со дестинацијата, како и поттикната соработка со други институции и туризам компании со цел да донесуваат одлуки и да преземат активности во врска со развојот на туризмот. Различни засегнати страни можат многу ефикасно да комуницираат со своите партнери, но истото за да можат да користат паметни технологии за комуникација со потенцијалните клиенти туристички услуги засновани на интерактивни платформи, страници, социјални мрежи итн. Важноста на паметниот туризам во градовите ја препознава Европскиот парламент, на чија иницијатива, Европската комисија ја доделува титулата европска престолнина на паметниот туризам за неколку европски градови, кои се најиновативни во однос на развојот на туризмот врз основа на четири критериуми: одржливост, пристапност, дигитализација и културно наследство и креативност. Главни конкуренти за титулата Европските метрополи на паметен туризам се градови на земјите од Европската унија кои имаат повеќе од 100.000 жители. ${ }^{24}$ За оваа титула, која беше доделена во 2018 година за следната година, Аплицираа 38 градови од 19 земјичленки на Европската унија. На градовите им суди група независни лица експерти, кои поседуваат знаење од областа врз основа на кои градови се рангирани. Европските метрополи на паметен туризам во 2019 година беа доделени на градовите Хелсинки и Лион. Веднаш до нив, беа избрани четири градови кои ја добија наградата за извонредни достигнувања во четири категории: Малага (пристапност), (одржливост), Копенхаген (дигитализација) и Линц (културно наследство и креативност). Еден од најрепрезентативните примери на дестинации, кој го воведува концептот на паметен развој и се стреми да стане паметна дестинација е Шпанија, во чија политика е развој на туризмот оваа идеја еден од стратешките приоритети. Како една од најпосетуваните дестинации во светот, Шпанија во текот на 2017 година ја посетиле околу 82 милиони туристи, со пораст од 8,9\% во споредба со претходната година. Секој турист за време на престојот во Шпанија постигна просечна потрошувачка на 1.061 евра, со вкупно трошење туристи во износ од околу 87 милијарди евра во текот на 2017 година, со пораст од 4,4\% во споредба со претходната година. ${ }^{25}$ Туристички дестинации како што се Палма де Мајорка, Марбела и Ла Палмас де Гран Канарија се примери на

\footnotetext{
${ }^{23}$ Del Chiappa, G. \& Baggio, R. (2015). Knowledge transfer in smart tourism destinations: Analyzing the effects of a network structure. Journal of Destination Marketing \& Management, 4 (3), 145-150.

24 http://www.lamoncloa.gob.es/lang/en/gobierno/news/Paginas/2018/20180110_balancetourist17.aspx, (datum pristupa 30.01.2019.)

25 http://www.lamoncloa.gob.es/lang/en/gobierno/news/Paginas/2018/20180110_balancetourist17.aspx, (datum pristupa 30.01.2019.)
} 
добро практики во примената на технолошките иновации во развојот на туризмот. Локалните власти на Палма де Мајорка основаше специјална услуга Smartofice, составена од тим за координација, претставници на локалното население, локалната самоуправа и јавни претпријатија. Оваа дестинација се фокусира на развој на иновации, информатички и комуникациски технологии и промоција на креативни идеи што ќе бидат корисни за дестинацијата во соработка со приватниот сектор. Некои од иницијативите се однесуваат на SmartWifi на плажите, кои се реализиран во соработка со општинскиот совет на Палма де Мајорка и Лукмајор со цел да се обезбеди безбедност бесплатен пристап до Интернет за туристите и локалното население и создавање телекомуникации шифрирана мрежа за податоци, што ќе им обезбеди на корисниците безбедност и мобилност. СМХ (Искуство за следење на клиенти) платформата користи мобилни апликации за студии однесување на туристите за време на нивниот престој во градот во реално време, додека Business Intelligence Paltform е платформа што ги прави информациите достапни за приватните компании сектор. Пример за добра практика е Марбела, чии локални власти ја препознаа нејзината важност технолошки достигнувања за развој на туризмот и формираше работна група наречена одбор за јавност.

\section{Основни карактеристики на туристичката понуда на градовите на Република Македонија}

\section{Општ пристап}

Во овој дел од трудот е направена анализа на туристичката понуда на градовите кои се носители на развојот на градскиот туризам на Република Македонија. Како дестинации, со чија туристичка понуда ќе се анализира аспекти на развојот на градскиот туризам во Македонија беа избрани следниве градови: Скопје, Охрид, и Прилеп.

\section{Главните критериуми за избор на овие градови беа:}

1. Структурата на туристичката понуда, што одговара на елементите што ја сочинуваат понудата на градскиот уризам. Предмет на анализа се значајни елементи на туристичката понуда како што се природни и антропогени ресурси, понуда за сместување, туристички атракции, сообраќајна инфраструктура, итн.

2. Население во Република Македонија

3. Застапеност на градови од сите региони на Република Македонија. Градови, кои се предмет на анализите припаѓаат на различни региони на Република Македонија: Скопје (Скопски регион), Охрид (југозападен регион), и Прилеп (Пелагониски регион)

4. Афирмација на градовите како туристички дестинации. Анализираните градови се привлечни туристички дестинации. Скопје, и Охрид се меѓу туристичките места од прва категорија, додека Прилеп е класифициран на второ туристичко место.

5. Квантитативни индикатори за развој на туризмот. Градови анализирани од година во година постигнуваат значајни резултати во однос на бројот на туристи. Процентот е исто така значаен индикатор за учество на странски туристи во вкупниот туристички сообраќај.

6. Покрај тоа, анализираните градови беа класифицирани како дестинации за градење слики градски туристички дестинации, кои се главни административни центри на Скопје и Охрид, додека Прилеп се идентификува како град со туристичка понуда што е соодветен во согласност со потребните предуслови за развој на градскиот туризам и кој има потенцијал да стани конкурентна дестинација за градски туризам. Прилеп и пелагонискиот регион се идеално место за просперитет на Верскиот туризам кој преставува една од најстарите форми на патување низ историјата во регионални и светски рамки. Историски гледано верскиот туризам има долга традиција кај нас кој го сочинуваат голем број на манастриски комплекси кои изобилуваат со големи конаци, манастирски живот и верски училишта во чија закрила низ историјата се засолнувале голем број 
на посетители и добронамерници. Денес постојат 270 манастири од кои 150 се сочувани и се од локален карактер и останатите 120 се во лоша состојба.

\section{Заклучок}

Во овој дел од трудот се дадени заклучни забелешки, кои се изведени врз основа на една целина истражувања кои се поврзани со стратешкиот пристап кон развојот на туризмот во градовите на Република Македонија.

Оваа единица е поделена на неколку сегменти со цел да се извлечат конкретни заклучоци: теоретски и практичен придонес на истражувањето, заклучоци од истражувањето, ограничувања на истражувањето, упатства за идно истражување како и упатства за иден развој на туризмот во градовите на Република Македонија

Предмет на истражување на овој труд е градскиот туризам, улогата на градовите во развој на туристичката и целокупната економија на Република Македонија, и врз основа на тоа, дефинирање на стратешките основи за развој на туризмот во градовите на Република Македонија. Со цел да се анализира поставениот објект за истражување, трудот применува теоретски и емпириски пристап. Во теоретскиот пристап опфатен е анализа на достапната домашна и меѓународна стручна литература за градскиот туризам, како и неговите основни карактеристики и елементи. Воспоставена е теоретска анализа на градскиот туризам за да биде комплексен предмет на истражување што е составен дел од развојот на туризмот. Сложениот карактер на субјектот на истражувањето е условен од фактот дека градскиот туризам е обединувач на различни форми на туризам за кои градот е просторна рамка за нивниот развој и дека оваа форма на туризам е поврзана со други форми на туристички активности во градовите. Покрај тоа, анализата на достапната литература открила дека во градовите, во однос на други видови дестинации, влијанието на сезоната не е изразено, односно туристите во текот на целата година ги посетуваат градовите за да ги задоволат туристичките потреби. Компаративна предност на градскиот туризам се рефлектира и во фактот дека нејзината понуда може да задоволи повеќе мотиви за патување на туристите и дека луѓето со различни социо-демографски карактеристики покажуваат интерес за посета на градовите. Врз основа на анализата на стручната литература може да се заклучи дека поради спецификите на неговата развој, градскиот туризам создава значителни, првенствено економски придобивки за една градска дестинација. Спроведената теоретска анализа ја постигна основната цел на истражувањето, што се осврна на посочување на важноста и мултифункционалноста на градовите како туристички дестинации со посебен акцент на важноста на градскиот туризам за развој на туризмот и економијата во Република Македонија.

\section{Придонес од практичното истражување}

Практичниот придонес на истражувањето се рефлектира во фактот дека резултатите од истражувањето можат да ги користат превозници на туристичка понуда со цел, врз основа на проценка на степенот на задоволство на туристите со одредени елементите на понудата за градски туризам да го подобрат нивниот квалитет, а со тоа и нивниот бизнис. Покрај тоа, резултатите од истражувањето им овозможуваат да стекнат увид во профилот на туристите кои престојуваат во градовите на Република Македонија, како и за нивните мотиви за патување и преференции. Од друга страна, државните институции, како и деловните здруженија од областа на туризмот, можат да ги видат резултатите на истражувањето за дефинирање на стратешки планови за подобрување на понудата и за градскиот туризам. Специјалните програми, чија имплементација ќе ги елиминира проблемите предизвикани од туристите изјавија дека повеќе нема да ги посетуваат градовите во земјата. На овој начин, може да се придонесе за решението на проблемите со кои се соочуваат носителите на туристичката понуда на градовите во Република Македонија, кои се 
идентификувани прецизно со испитување на нивните ставови за степенот на развој на градскиот туризам.

Табела 3. Приказ на контактот со испитаниците

\begin{tabular}{|c|c|c|}
\hline ПРВ КРУГ НА ИНТЕРВЈУ/ДЕБАТА & УЧЕСНИЦИ & ВТОР КРУГ НА ИНТЕРВЈУ/ДЕБАТА \\
\hline 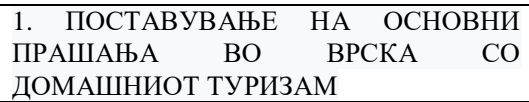 & $\begin{array}{l}\text { 1. ПРЕТСТАВНИЦИ ОД ЛОКАЛНИТЕ } \\
\text { САМОУПРАВИ НА ТУРИСТИЧКИТЕ } \\
\text { ГРАДОВИ }\end{array}$ & $\begin{array}{l}\text { 1. СУМИРАњЕ НА } \\
\text { ПОДАТОЦИ ОД ПРВИОТ КРУГ }\end{array}$ \\
\hline $\begin{array}{l}2 . \text { ПРАШАЮЕ ВО ВРСКА } \\
\text { ОРГАНИЗИРАЬЕ НА СИТЕ ФОРМИ НА } \\
\text { ТУРИЗАМ ВО ГРАДОТ }\end{array}$ & $\begin{array}{ll}2 . & \text { ПРЕСТАВНИЦИ } \\
\text { ТУРИСТИЧКИТЕ АГЕНЦИИ ОД РМ }\end{array}$ & $\begin{array}{l}\text { 2. ДЕБАТИРАњЕ ВО ВРСКА СО } \\
\text { СУМИРАНИТЕ ПОДАТОЦИ ДОБИЕНИ } \\
\text { ОД ПРВИОТ КРУГ }\end{array}$ \\
\hline $\begin{array}{lll}\text { 3. ПРАШАҢА ПОВРЗАНИ } & \text { СО } \\
\text { ХИГИЕНАТА И ДИСЦИПЛИНАТА НА } \\
\text { СЕКОЈ ОРГАНИЗИРАН ЕВЕНТ } \\
\text { ГРАДОТ }\end{array}$ & $\begin{array}{l}\text { 3. } \text { АГЕНЦИЈА ЗА ПОДРШКА } \\
\text { ПРОМОЦИЈА НА ТУРИЗМОТ }\end{array}$ & $\begin{array}{lr}\text { 3. ДАВАЮЕ НА } \\
\text { ПОДОБРУВАЮЕ НА СИТЕ СЕГМЕНТИ } \\
\text { НА } \\
\text { ДЕСТИНАЦИЈА }\end{array}$ \\
\hline $\begin{array}{l}\text { 4. ПРАШАҢА ПОВРЗАНИ } \\
\text { УПРОСТУВАЮЕТО НА ПОСТАПКИТЕ } \\
\text { ЗА ОРГАНИЗИРАҢЕ НА РАЗЛИЧНИ } \\
\text { ФОРМИ НА ТУРИЗАМ }\end{array}$ & $\begin{array}{l}\text { 4. ПРЕТСТАВНИЦИ ОД ДРЖАВНИТЕ } \\
\text { ИНСТИТУЦИИ }\end{array}$ & 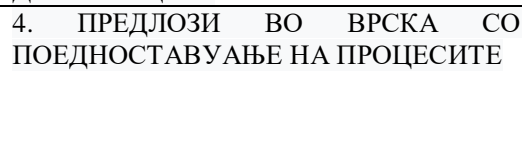 \\
\hline $\begin{array}{l}\text { 5. ПРАШАЮЕ } \\
\text { ПОТРЕБИТЕ НА СОКОЛА ЛОКА СО } \\
\text { САМОУПРАВА ЗА УНАПРЕДУВАНЕ } \\
\text { НА ТУРИСТИЧКАТА СЛИКА }\end{array}$ & $\begin{array}{l}\text { 5. ПРЕТСТАВНИЦИ ОД ФАКУЛТЕТ ЗА } \\
\text { ТУРИЗАМ И УГОСТИТЕЛСТВО ВО РМ }\end{array}$ & $\begin{array}{l}\text { 5. ДОНЕСУВАЮЕ НА ЗАКЛУЧОЦИ } \\
\text { ДОБИЕНИ ОД ПРАШАЬАТА }\end{array}$ \\
\hline 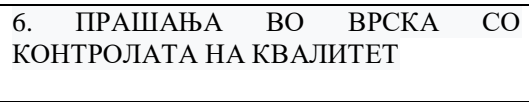 & $\begin{array}{l}\text { 6. ПРЕТСТАВНИЦИ } \\
\text { МИНИСТЕРСТВАТА ЗА ЕКОНОМИЈА } \\
\text { И ФИНАНСИИ }\end{array}$ & $\begin{array}{l}\text { 6. ДОНЕСУВАЮЕ НА ЗАКЛУЧОЦИ } \\
\text { ДОБИЕНИ ОД ИЗВРШЕНАТА ДЕБАТА }\end{array}$ \\
\hline $\begin{array}{l}\text { 7. ПРАШАЫА } \\
\text { БЕЗБЕДНОСТА } \\
\text { НА } \\
\text { ДЕСТИНАЦИИ }\end{array}$ & 7. УПРАВАТА ЗА ЈАВНИ ПРИХОДИ & $\begin{array}{l}\text { 7. ПРЕЗЕНТАЦИЈА НА ДОБИЕНИТЕ } \\
\text { ЗАКЛУЧОЦИ }\end{array}$ \\
\hline
\end{tabular}

Практичниот придонес на истражувањето беше постигнат со воспоставување контакт со испитаниците, чии мислења се релевантни во собирањето, обработката и анализата на ставовите за развојот на градскиот туризам во земјата. Резултатите од истражувањето можат да бидат корисни и за туристите кои имаат намера да ги посетат градовите во Република Македонија, за да можат врз основа на степенот на задоволство на туристите кои веќе престојувале да формираат одредени очекувања од туристичката понуда на градот во кој планираат да останат. 


\section{П Р А Ш А Л Н И К бр. 1}

(Прашалникот е изработен на 20.01.2021)

Прашалникот е наменет за одреден број на туристи (30) кои претстојувале на некој евенти и манифестации во туристичките дестинации на Република Северна Македонија.

1. Дали сте задоволни од услугите за време на вашата посета на туристичката дестинација во Република Северна Македонија? а) да

б) делумно

в) не

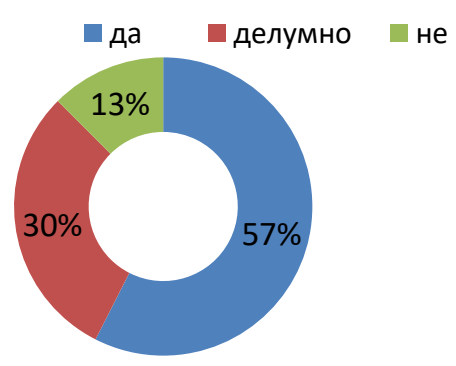

Коментар: Мнозинство од испитаниците $(57 \%)$ се задоволни од услугите но имаме и голем дел од $43 \%$ кои се делумно и не задоволни што ни укажува дека треба да се работи на подобрување на услугите со цел да се зголеми процентот на задоволни туристи.

2. Кои нови услуги и информации би сакале да ги добиете од страна на организаторите на евентот во градскиот туризам? а) бесплатен превоз до евентот $\quad$ б) бесплатен паркинг в) Креирање и користење на голем број на графички пропагандни средства г) бесплатен туристички водич

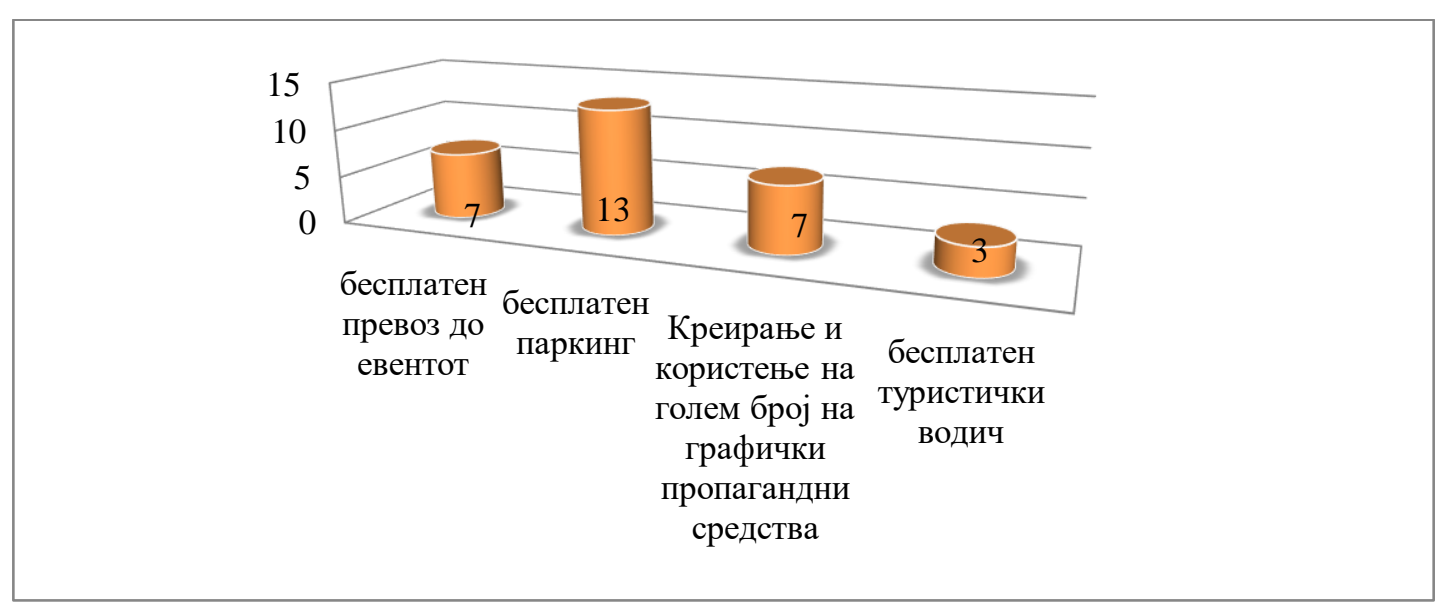

Коментар: Според резултатите локалната самоуправа треба да посвети поголемо внимание на овозможување на паркинг простор за сите гости во туристичката дестинација.

3. Дали сте задоволни од капацитетите за сместување во туристичките дестинации на Република Северна Македонија.
а) да
б) не
в) делумно 


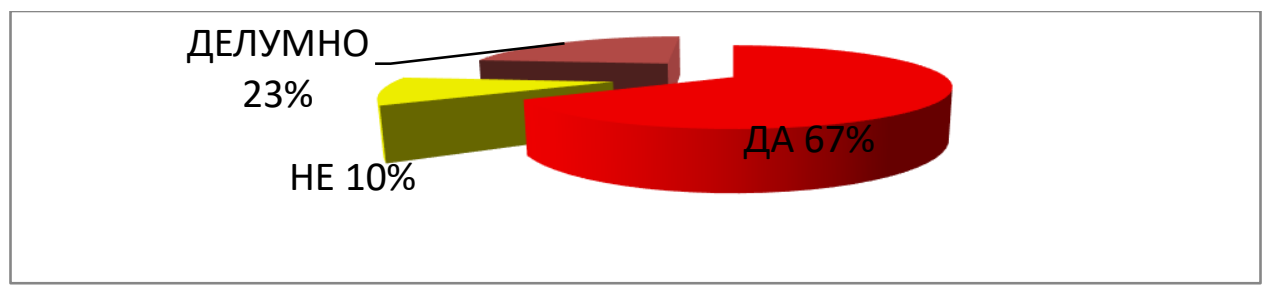

Коментар: Најголем дел (67\%) се задоволни од сместувачките капацитети но имаме $33 \%$ кои се делумно и не се задоволни што ни укажува на тоа дека во иднина треба да се зголемат сместувачките капацитети се со цел да се сместат што повеќе гости.

4. Дајте своја оценка од 1 до 5 за квалитетот на добиените услуги.

\begin{tabular}{|c|l|l|l|l|l|}
\hline & $\mathbf{1}$ & $\mathbf{2}$ & $\mathbf{3}$ & $\mathbf{4}$ & $\mathbf{5}$ \\
\hline $\begin{array}{c}\text { Однос на } \\
\text { вработените }\end{array}$ & $0 \%$ & $7 \%$ & $15 \%$ & $23 \%$ & $55 \%$ \\
\hline $\begin{array}{c}\text { Квалитетот на } \\
\text { добиените } \\
\text { услуги }\end{array}$ & $0 \%$ & $5 \%$ & $10 \%$ & $20 \%$ & $65 \%$ \\
\hline $\begin{array}{c}\text { Брзината на } \\
\text { давање на } \\
\text { услугите }\end{array}$ & $5 \%$ & $10 \%$ & $10 \%$ & $25 \%$ & $50 \%$ \\
\hline
\end{tabular}

\section{Одговорите се изразени во проценти\%}

Коментар: Највисоки оценки имаме во делот за квалитет на услугите а во делот за однос на вработените и брзината на давање на услуги треба да се посвети поголемо внимание се со цел да се постигне поголемо задоволство кај туристите.

5. Какво е вашето досегашно искуство од комуникацијата со домаќините на туристичката дестинација која ја посетивте во Република Северна Македонија?

a) Секогаш услужливи и достапни б) Недостапни и неуслужливи в) Задоволитено

Секогаш услужливи и достапни шедостапни и неуслужливи Задоволитено

Коментар: Прикажаните резултати ни укажуваат дека имаме само 7\% кои сметаат дека комуникацијата е на ниско ниво што е знак дека комуникацијата е на високо и задоволително ниво.

6. Како ќе го оцените искуството од досегашните посетени туристички дестинации?

а) позитивно б) негативно 


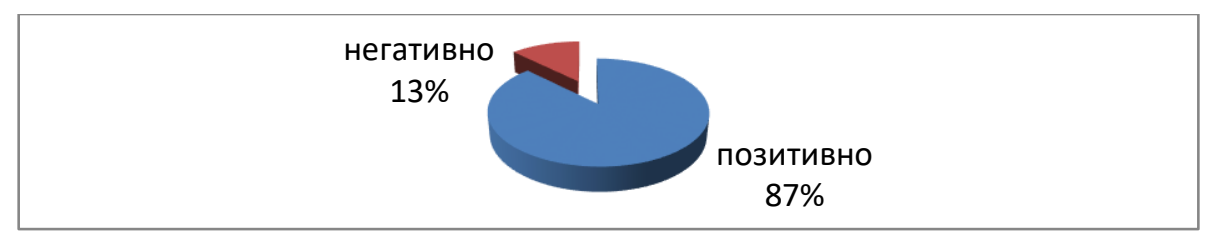

Коментар: Имаме огромен процент на позитивни искуства што ни укажуваат за успешна реализација.

7. Дали сте задоволни од туристичките дестинации и евенти кои ги посетивте во Р. Македонија?

\section{Одговорите се изразени во проценти\%}
а ) задоволен
$90 \%$
б) делумно задоволен
$7 \%$
в) незадоволен
$3 \%$
8. Возраст: а) 20-30 год. б) 30-40 год. в) 40-50 год. г) над 50 год.

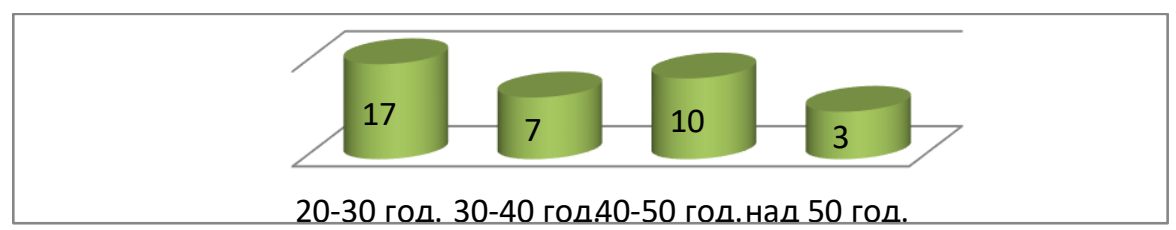

\section{9. Дали сте вработен?}

\section{Одговорите се изразени во проценти\%}
а) ДА $70 \%$
б) $\mathrm{HE} 30 \%$

10. Доколку сте вработен,работите во:Одговорите се изразени во проценти\%,
а) Државна институција 30\%,
б) Приватна фирма $30 \%$,
в) АД $15 \%$
г) Локална самоуправа 20\%, д) Друго 5\%

11. Мотив за доаѓање
А) Љубител на добра храна 50\%
Б) Љубител на Добро пиво 30\%
В) Љубител на Добра Забава $20 \%$

12. Начин на доаѓање

А) Автомобил $60 \%$, Б) Воз 10\%, В) Автобус 10\%, Г) Такси $20 \%$

13. Сместувачки капацитети

a) Хотел $40 \%$, б) Хостел $20 \%$, в) приватен смештај 20\%, г) шатор $10 \%$

\section{4. Квалитет на сместувачки капацитети}

a) Одличен $60 \%$, б) Задоволителен $20 \%$, в) добар 15\%, г) лош 5\% 


\section{П Р А Ш А Л Н И К Бр. 2}

(Прашалникот е направен на 20.01.2021)

Прашалникот е наменет за сите вработени во туристички компании, јавен сектор, државни институции и деловни здруженија од областа на туризмот. Прашалникот е анонимен и изготвен преку анкета извршена на (40) вработени од горенаведените институции. Резултатите ќе се користат за подобрување на меѓусебната комункации на горенаведените субјекти , степенот на развој на градскиот туризам, важноста на одредени елементи на туристичката понуда, како и околу потенцијални проблеми со кои се соочуваат носителите на туристичката понуда во развојот, промоцијата и пласманот на сите форми на туризам.

1. Дали мислите дека Вашето образование е соодветно со Вашето работно место?
а) да $80 \%$
б) не $20 \%$

2. Дали сте задоволни од условите за работа?
а) да $70 \%$
б) не $30 \%$

3. Каков е односот на непосредното одговорно лице со ангажираните во овој туристички евент?
a) Позитивен
б) Негативен
в) Коректен

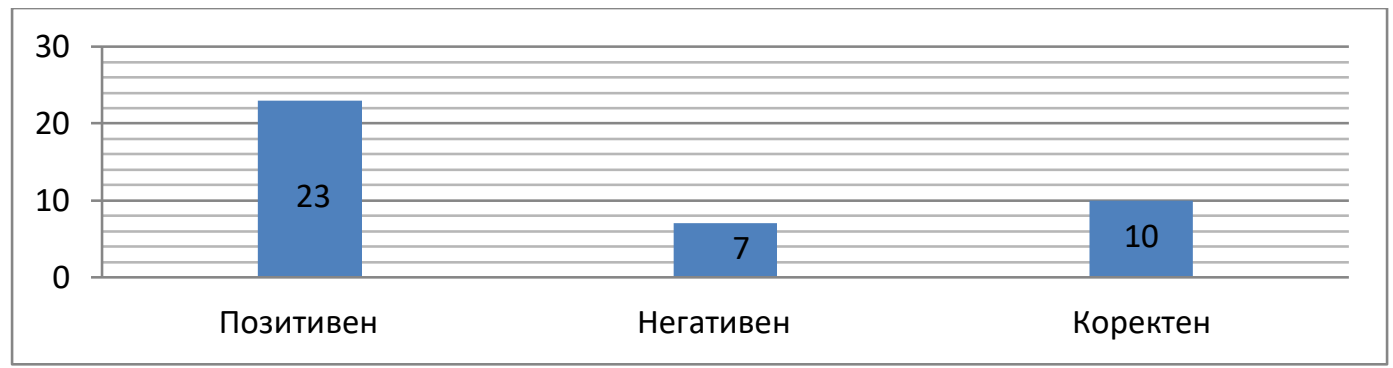

Коментар: Според одговорите односот на одговорното лице е позитивен и коректен но имаме и негативни одговори што ни укажува дека секое одговорно лице треба да работи на односот со сите ангажирани во туристичктата дестинација или во одредениот евент.

4. Дали сте задоволни од флексибилноста, интеракцијата со непосредното одговорно лице?
a) да
б) делумно
в) не

口да пелумно не не


Коментар: Овие резултати ни укажуваат на поделени мислења што значи дека секое одговорно лице треба да посвети поголемо внимание со своите претпоставени и да работи пофлексибилно и по транспаретно.

5. Дали сте задоволни од работата на ангажирани или вработени во Вашиот сектор? (доколку сте одговорен во одреден сектор одговарате на прашањето)
а) да
б) делумно
в) не

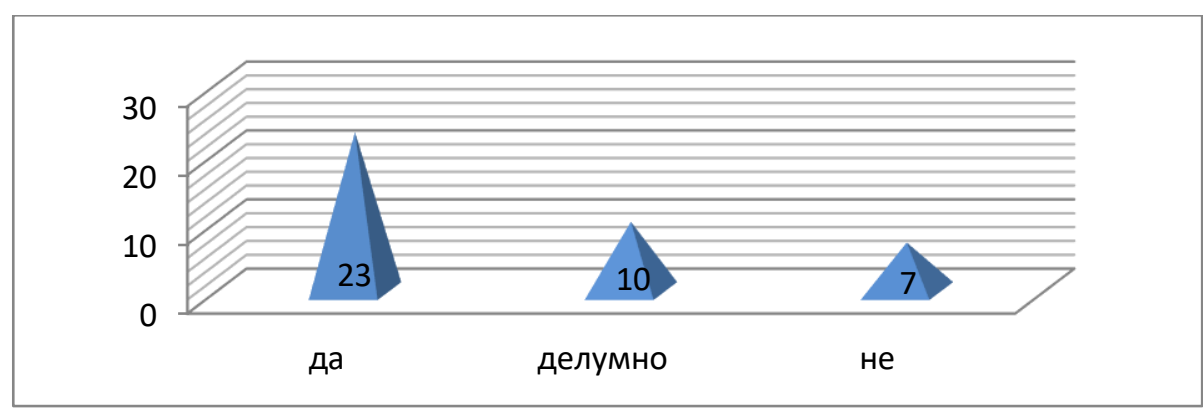

6. Како би го оцениле развивањето на доверба и соработка меѓу сите соработници во туризмот во вашата туристичка дестинација?
а) задоволително
б) одлично
в) незадоволително

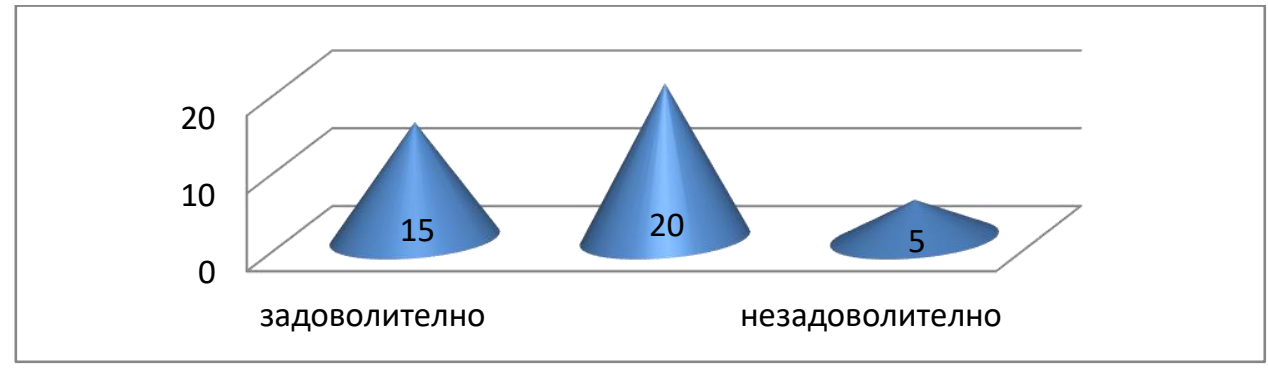

7. Дали сте запознаени со сите информации за организирање на сите форми на туризам во вашата туристичка дестинација?
а) да
б) делумно
в) не

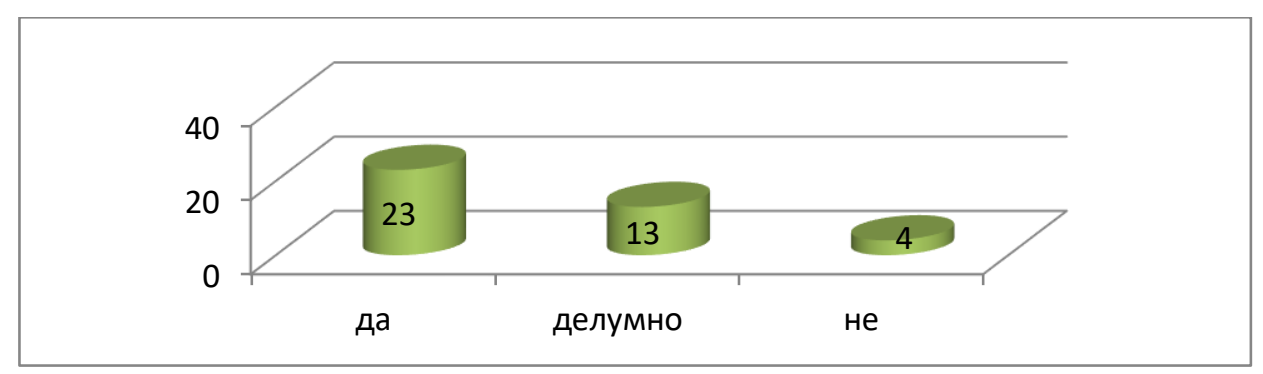


8. Дали постапувате согласно насоките дадени од страна на одговорното лице во вашиот сектор?
а) да $90 \%$
б) делумно $10 \%$
в) не $0 \%$

9. Колку сте задоволни од спроведените мерки за заштита на животната средина?
а) задоволни $70 \%$
б) незадоволни $30 \%$

10. Дали сте задоволни од организирање на обуки за подобрување на ефикасноста во работењето?
а) да $60 \%$
б) не $40 \%$

11. Дали се соочувате со стрес на работното место?
a) да $40 \%$
б) делумно $40 \%$
в) не $20 \%$

12. Дали давате иницијативи за подобрување на работната ефикасност и успешноста на оваа организација во целина?
а) да $70 \%$
б) не $30 \%$

13. Дали иницијативите се разгледуваат и прифаќаат од страна на одговорните лица? (доколку на претходното прашање е одговорено со Да)
а) да
б) делумно
в) $\mathrm{He}$

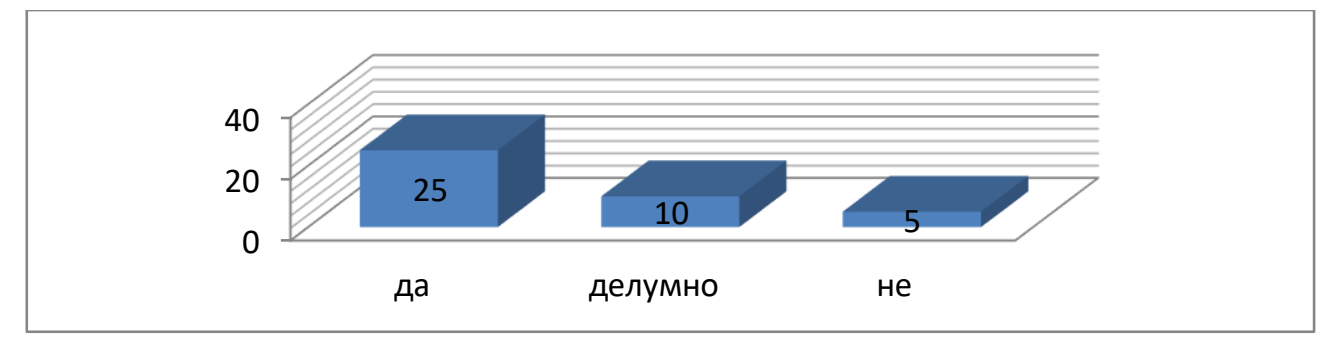

14. Кој од овие предлози е најдобар за подобрување на работната клима и меѓучовечките односи: а) Организирање на туристички семинари б) Вршење меѓусебна десеминација на стекнатото знаење в) Работа во тимови г) Вршење на континуирана обука во туризмот и угостителството

Коментар: Вршењето на континуирана обука е најдобар предлог со кој би се подбрила работната клима во една органзација според испитаниците.

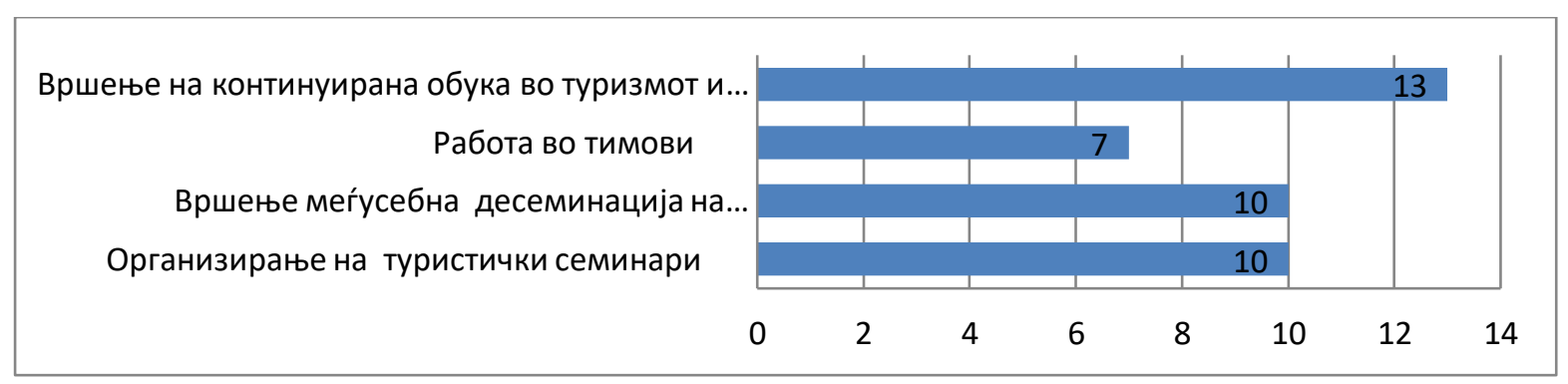




\section{Заклучоци од истражувањето}

Со цел да се тестираат хипотезите, беа спроведени две истражувања. Предмети на првото истражување биле туристи кои престојувале во градовите на Р. Македонија и одговарале на прашања за: начинот на организација за нивното патување, степенот на задоволство од постојната понуда на градовите во Републиката Македонија и нивните идни намери кога станува збор за престој во градовите на територијата на нашата земја но и во други видови туристички дестинации (планински центри, бањи и климатски места и сл.). Во друга студија, фокусот беше насочен кон испитување на ставовите на вработените во туристичките компании економија, претпријатија за комплементарни активности, јавен сектор и деловни здруженија од области на туризам. Целта на ова истражување беше да се добие увид во ставовите на вработените за моменталната состојба степенот на развој на градскиот туризам, важноста на одредени елементи на туристичката понуда, како и околу потенцијални проблеми со кои се соочуваат носителите на туристичката понуда во развојот, промоцијата и пласманот на овој туристички производ.

Преку овие прашалници се утврдуваат и се подобруваат услугите односно со пополнувањето на овие прашалници се придонесува во процесот на подобрување на туристичката слика за една туристичката дестинација. Исто така може да се напомене дека современите форми на туризам го истакнуваат значењето на задоволството на сите физички лица и правни субјекти кои се вклучени во организацијата на евентот или манифастација во одредената туристичка дестинација. Се докажа дека овие се најефикасните начини за креирање и поттикнување квалитетна и продуктивна организација која ќе работи успешно во примената на сите алатки за подобрување на туристичката слика за Р. Македонија во меѓународни рамки.

\section{Референци}

1. Pearce, D. (2001). An Integrative Framework for Urban Tourism Research. Annals of Tourism Research, 28 (4),p. 926.58

2. Cosma, S. A. (2012). Measurement Tourism Performance of Urban Destinations. Journal of Travel and Tourism Research (Online), 12 (1), p. 51

3. Cave, J. \& Jolliffe, L. (2012).Urban Tourism: The Key Concepts. Robinson, P. (Ed.) London: Routledge, p. 268

4. Peroš, L. (2013). Affirmation of cultural identity tourism destination through city break travelling-Zadar cityexample. The Third International Scientific Congress-Biennale: Icon Best 2013, Skopje, Makedonija, 5-7 August2013, p. 226.

5. Prideaux. B. (2009). Resort Destinations - Evolution, Management and Development. Elsevier Ltd, p. 10.

6. Jansen-Verbeke, M. (1986). Inner-City Tourism: Resources, Tourists and Promoters. Annals of Tourism Research, 13 (1), p. 85.

7. Shoval, N. \& Raveh, A. (2004). Categorization of tourist attractions and the modeling of tourist cities: based on the co-plot method of multivariate analysis. Tourism Management, 25 (6), p. 741

8. Ashworth, G. J. \& Tunbridge, J. E. (2000). The tourist-historic city. Routledge. p. 131-132

9. Dunne, G., Flanagan, S. \& Buckley, J. (2011). Towards a decision making model for city break travel. International Journal of Culture, Tourism and Hospitality Research, 5 (2), p. 159.

10. Charterina, J. \& Aparicio, G. (2015). A comparison of antecedents of satisfaction in city break traveling. Revista Española de Investigación En Marketing ESIC, 19 (2), p. 73.

11. Rabotić, B., (2013). City break putovanja - selektivni oblik turizma. Casopis Hotel Link, 21-22, str. 584.

12. Dunne, G., Flanagan, S. \& Buckley, J. (2011). Towards a decision making model for city break travel. International Journal of Culture, Tourism and Hospitality Research, 5 (2), 158-172. 
13. WTTC. (2019). Travel \& tourism economic impact 2019 world. Dostupno na: https://www.wttc.org/-

/media/files/reports/economic-impact-research/regions-2019/world2019.pdf, (datum pristupa 20.04.2019.), p. 6.

14. Getz, D. (2007). Event studies: theory, research and policy for planned events. Butterworth Heinemann, Oxford, p. 18.

15. International Communication Union, https://www.itu.int/en/ITUD/Statistics/Pages/stat/default.aspx, (datum pristupa 28.01.2019.)

16. Anthopoulos, L. (2015). Defining smart city architecture for sustainability. U: Tampouris, E. Et al.

(Eds).

Proceedings of the 14th IFIP Electronic Government (EGOV) and 7th Electronic Participation (ePart) Conference 2015, 30 August - 2 September, 2015, Thessaloniki, Greece,IOS Press, Amsterdam, p. 140

17. Berry, C. R. \& Glaeser, E.L. (2005). The divergence of human capital levels across cities. Papers in Regional Science, 84 (3), p. 438.

18. Meijer, A. \& Bolivar, R. P.M. (2016). Governing the smart city: a reviewof the literature on smart urbangovernance. International Review of Administrative Sciences, 82 (2), p. 396.

19. Caragliu, A., Del Bo, C. \& Nijkamp, P. (2011). Smart cities in Europe. Journal of urban technology, 18 (2), p. 47-48

20. Mahizhnan, A. (1999). Smart cities: the Singapore case. Cities, 16 (1), p. 14-17.

21. Barrionuevo, J. M., Berrone, P. \& Ricart, J. E. (2012). Smart cities, sustainable progress. IESE Insight, 14 (14), p.51.

22. Del Chiappa, G. \& Baggio, R. (2015). Knowledge transfer in smart tourism destinations: Analyzing the effects of a network structure. Journal of Destination Marketing \& Management, 4 (3), 145-150.

23. http://www.lamoncloa.gob.es/lang/en/gobierno/news/Paginas/2018/20180110_balancetourist17.a spx, (datum pristupa 30.01.2019.)

24. http://www.lamoncloa.gob.es/lang/en/gobierno/news/Paginas/2018/20180110_balancetourist17.a spx, (datum pristupa 30.01.2019.) 